International Review of Social History 44 (1999), pp. 249-300

(C) 1999 Internationaal Instituut voor Sociale Geschiedenis

\title{
SURVEY
}

\section{Industrial Labour in Post-Colonial India I: Industrializing the Economy and Formalizing Labour*}

\author{
JAN BREMAN
}

\section{CONSTITUTING LABOUR}

In post-colonial India labour was given the connotation of work in industry. The labourer as a social figure became linked to the modern economy, a direction in which Indian society was to develop at a rapid rate. The agrarian-rural mode of life and work would soon fade away to be replaced by an industrial-urban order. The close association of labour economics with industrial employment was a logical consequence of this restructuring. The expectation of the transformation that was going to take place makes it understandable why authors of authoritative textbooks on the shape of the working class and the trade union movement were able more or less to ignore the non-industrial way of life of the large majority of the working population. ${ }^{\mathrm{I}}$

The mandate of the National Planning Committee, set up in 1940 by the All India Congress Committee and led by Jawaharlal Nehru, was to operationalize the nationalist mission and, more concretely, to formulate the policies that were to be executed after the declaration of Independence. This august forum based its directives on deliberations held in working groups on a number of themes. One of these was the working group on "labour". It had among its members R. Mukerjee, V. V. Giri, A. Sarabhai on behalf of industrial employers, and as rapporteur N. M. Joshi, a prominent trade union politician and loyal pillar of the anything-but-militant Congress line. G. Nanda was present by special invitation. It is interesting that this consultative body, charged with designing a planned economy, totally ignored the Gandhian doctrine of small-scale village development in which agriculture was interwoven with crafts and trades.

The minutes of the meetings held by the working group on labour show

\footnotetext{
* The second part of this survey will be published in Part 3 of this volume. A bibliography with the full references will appear at the end of this second part.

I. Pant, Indian Labour Problems; Singh, Labour Economics; Sen, Working Class of India; Crouch, Indian Working Class.
} 


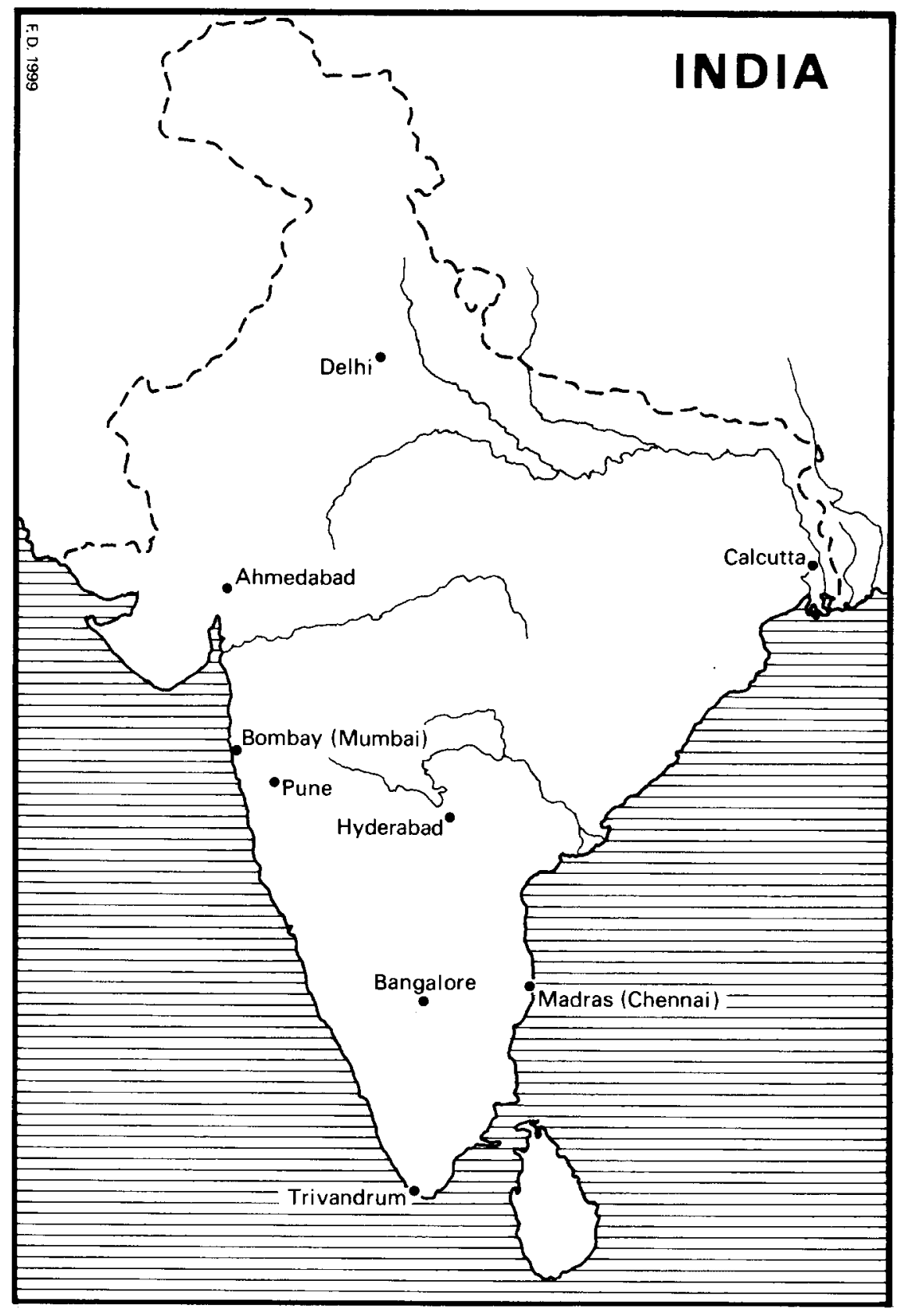

Figure I. India 
that only those issues were discussed that had to do with the regulation of industrial relations, e.g. working hours (forty-eight hours per week, nine hours per day), the health and safety of the workforce, social security, housing, etc. The regulations proposed in these respects were modelled on labour practices that were already operative in the industrialized part of the world where the working-class movement had become a major social force. The reason why discussions focused so much on these features was that only in the industrial sector of the economy had a trade union movement evolved which set itself the task of representing workers' interests. But of even greater importance were the implications of the leading role attributed to the state in the transformation towards industrial society. The common understanding was that laying the foundation of a modern industrial infrastructure required huge investments which could not be mobilized by relying on private business alone. The active participation of the state in restructuring the economy, in particular for the production of capital goods on the basis of advanced technology, met with the unreserved approval of private enterprise. ${ }^{2}$ In the planning scenario that emerged the public and private sectors would reinforce rather than compete with each other. The strategic role thus played by the post-independent state in bringing about industrialism facilitated the public regulation of terms and conditions of employment, first and foremost in the new and modernized sectors of the national economy.

The labour legislation that was soon introduced allotted to the government considerable power regarding the definition of industrial procedures and the solving of disputes between employers and workers. This statist engagement led to the setting up of a massive machinery charged with administration and registration, inspection, arbitration and adjudication, and other tasks exclusively concerned with labour and employment in what was later to be called the organized sector of the economy.

At the start of the post-colonial era India had less than ten million industrial workers, of whom considerably less than half were subject to a labour regime that could be called factorized. In 1950, according to Ornati, ${ }^{3}$ this applied to 2.75 million workers. If we adhere to the higher figure of ten million, this category of industrial labourers formed less than six per cent of the total workforce; even in the non-agrarian sector the magnitude of that workforce was of small significance, with barely seventeen per cent. ${ }^{4}$ Nevertheless, the literature describes this small minority as the prototype of the labour force that was to determine the future of land and people.

[...] their importance does not lie in numbers. This small section of the total labour

force is important because growth and expansion of the economy depends, to a

2. Ray, Industrialization in India.

3. Ornati, Jobs and Workers in India, p. 9.

4. Pant, Indian Labour Problems, p. I2. 
large extent, upon its attitude towards industrialisation. It being the only section where labour organisation exists and can grow easily, it can influence the pace of change. It is this section which along with its problems will grow with the progress of industrialisation. ${ }^{5}$

The far-reaching effects of the foreseen remodelling of society are illustrated by the fact that, since the beginning of the twentieth century, hardly any change had occurred in the relative size of the labour force employed in the secondary economic sector. In I9OI and 196I, industry, mining and plantation agriculture employed I2.6 and II.7 per cent respectively of the working population. ${ }^{6}$ The reason why labour was nevertheless mainly discussed in terms of industrial employment was due not only to the fact that it would become dominant in the near future, as soon as the sectoral shift was to get under way, but also to the political significance that was attributed to this mode of production. The post-colonial economy was designed according to plan and was meant to have a socialist orientation. Industrial employment was the model on which this not so far distant future was to be shaped, in which employers, workers and state would attune their separate interests to the common good. Pant referred to this agenda in the preface to his book: "This book studies Indian labour problems and policies in the context of planned economic development and the objective of the establishment of a socialist society." ${ }^{p}$

Even when the industrial breakthrough failed to materialize, when the planning principle became far less significant in policy execution and the latitude allowed to social forces followed another orientation than socialist ordering and a concomitant shift took place from the public to the private sector, the term "labour" continued to hold the connotation that it meanwhile had acquired: employment in the organized sector of the urban economy in general, and factorized production in particular. The transformative scenario was founded on the assumption that a social system would eventually emerge similar to that which had already developed in the West. The economist Raj referred approvingly to an early statement made by the later President Zakir Hussain, before Independence, to the effect that Asiatic and Indian capitalism would essentially differ little from the manner in which this mode of production had persevered in the West. ${ }^{8}$ This persistent adherence to the assumption of parallel development meant that, in the last instance, there were no fundamental doubts regarding the switch to an urban-industrial society. In reflecting on what the future looked like, not much thought was given to the variations, determined by local conditions

5. Ibid.

6. Ibid., p. Io.

7. Ibid., in the Preface.

8. Papola et al., Labour, Employment and Industrial Relations, p. 2II. 
and historical continuity, that had regionally emerged in the formation of the working class in the Atlantic part of the world. Exceptionalism was not the point of departure but adherence to evolutionary schemes which dominated social science theory and practice in the post-colonial era. In his critique of the universalist view of working-class dynamics, Chakrabarty elaborated on the specificities of the Indian case. ${ }^{9}$

The acceleration that occurred in the migration of labour from the countryside towards the large and middle-sized cities seemed to herald the approaching transformation in the subcontinent of South Asia. Between I9OI and 196I the urban share in the total population rose from four to eighteen per cent. Completely ignored, however, was the fact that, in the intermediate regime that still prevailed, only a tiny portion of the working population was employed in modern factories. Little consideration was given to the question of how the remainder, i.e. the greater part of the workforce in the cities, managed to earn a living. Also disregarded was the huge number of labourers who, although working for big industrial enterprises, did so in the rural hinterland, far removed from the urban milieu. This applied in particular to mineworkers and plantation coolies, a workforce far larger than that incorporated in the factories of Mumbai and Calcutta. Exceptions deserve to be mentioned. For example, in his study of the working class Mukerjee did not restrict himself to labour in the textile and metal industries, but also discussed working conditions in mining and the plantation corporations. ${ }^{10}$ Chandra did the same. ${ }^{\text {II }}$ Nevertheless, neither author gave any attention to waged labour in agriculture. In their analyses the countryside was the supplier of a workforce which belonged to the peasantry until the moment of departure.

The preoccupation with industrial employment detracted attention not only from the great segment of the urban population that earned its living in other ways, but even more from the social relations of production in agriculture. Iyer was one of the few early nationalist authors who specifically drew attention to agricultural labour as a separate social formation. Already at the start of the twentieth century he commented on the miserable fate of the landless in the village economy. ${ }^{\mathrm{I} 2}$ Post-colonial policy-makers only very slowly came to realize that agricultural labourers constituted the largest single section of the labour force. ${ }^{13}$ Early in the 1950 nationwide investigations showed that this rural under-class included roughly one-quarter of the agrarian population. The industrial proletariat, even at its maximum definition, was far smaller in size than the army of agricultural labourers. How was it, then, that this enormous rural workforce was ignored for so

9. Chakrabarty, Rethinking Working-Class History.

Io. Mukerjee, Indian Working Class.

II. Chandra, Rise and Growth of Economic Nationalism.

12. Iyer (1903) in Chandra, Rise and Growth of Economic Nationalism, p. 762.

13. Thorner, Land and Labour in India, p. 173. 
long? Its systematic neglect began in the colonial era and was linked to the stereotyped image of the rural order as a fairly homogeneous community, a massive volume of peasant producers at work in the fields mainly on their own account and at their own risk. The lack of differentiation accorded to land ownership and the emphasis on subsistence agriculture, both assumptions that caused a strongly biased image of the late-colonial situation, obstructed any view of the presence of a very sizeable agrarian underclass in large parts of South Asia. Attention was drawn to it incidentally, but case studies such as that of Lorenzo received little notice and were considered even less in the context of wage labour and its diverse modalities in Indian agriculture. ${ }^{I 4}$ Patel was one of the first to study the existence and growth of agricultural labour in South Asia. In essence, his account endorsed the thesis of agrarian regression in the late-colonial era which had many adherents in nationalist circles. Under alien rule, the original village community formed by a collectivity of peasants and artisans was said to have been broken-up in a process of economic differentiation into a minority of producers who had been able to maintain their independence (one-fifth), an impoverished class of small peasant-owners as well as tenants and sharecroppers (one-half), and a residual class (one-third) whose members had not been able to consolidate themselves even as dependent cultivators and who, having fallen into a state of complete landlessness, had no choice but to work for others in order to ensure their own survival. ${ }^{15}$ Kumar objected to this received wisdom in a study in which she established that landless labour formed a substantial social class in south India even in early colonial times, calculating that they represented seventeen to twenty-five per cent of the total agrarian population. ${ }^{16}$ In view of the significance of cottage industries and handicrafts in the countryside at the start of the nineteenth century, this could be equated with at least ten to fifteen per cent of the entire working population. Her conclusion then led Kumar to study the social identity and mode of employment of agricultural labour in both the pre-colonial and colonial past. She demonstrated that the great mass of landless people came from low castes and that their working status was given shape in servile labour arrangements based on bondage. Various village monographs written in the colonial era, for example those on south Gujarat by Mukhtyar and Shukla, confirmed labour bondage as being the hallmark of the relationship then existing between members of peasant castes among whom cultivable land was largely concentrated, and members of the landless castes subjugated to them in the rural economy. ${ }^{17}$

16. Kumar, Land and Caste in South India.

17. Mukhtyar, Life and Labour in a South Gujarat Village; Shukla, Life and Labour in a Gujarat Taluka. 
Was it because of the state of captivity that marked the agrarian regime that the landless masses were not defined as labourers and brought under the same denominator as industrial workers? The latter proletariat had after all freed themselves from extra-economic coercion. Such reasoning, however, makes no allowance for the fact that fairly large-scale use was made of indebtedness in recruiting workers from the peasant landscape, not only for coal mines and tea plantations but also for harbours and factories in large cities. Labour contractors and other intermediaries played an important role in mobilizing labour in a situation of bondage. The classic thesis that industrial capitalism only comes about when the transition to free labour has occurred in a dual sense - detached from the ownership of means of production, and able to decide for themselves how and where to sell their labour power - has proven not applicable to the colonial situation. ${ }^{18}$

Recent years have seen an interesting discussion regarding whether bonded labour was "traditional" by nature and had disintegrated in the course of time or, on the other hand, whether it should be seen as indicating the penetration of capitalism into the agrarian production sphere. Like many others, I count myself, with all appropriate qualifications, an advocate of the first interpretation. ${ }^{19}$ The contrary view has been defended first by Mundle and subsequently by Prakash. ${ }^{20}$ In doing so, the latter referred to the capitalist market effect combined with the colonial exercise of power which changed the subaltern kamia in south Bihar into a landworker in debt bondage. In extending the logic of this thesis to the present day, Patnaik posits that the further development of capitalist forces in agriculture will cause the augmentation of semi-feudal forms of labour bondage. "[...] bondedness of labour is not a static phenomenon. While debt bondage has always existed, we may expect it to increase rather than decline, given the increasingly desperate economic situation faced by rural labour" ${ }^{22}$ Brass has adopted this idea of increasing practices of labour bondage with even more aplomb. Disagreeing with studies by Harriss and Epstein pertaining to agrarian dynamics in south India, Brass, in his first article on the subject, criticizes their refusal to see what he saw: the enormous rise of bonded labour. In Harriss's own research locale, according to Brass, this was by no less than 243 per cent between 1955 and $1970 .^{22}$ This remarkable assertion, unsupported by empirical data, is highly questionable. Brass maintains that extreme position in subsequent articles. In controversial fashion, he disputes any attempt to deprive the distinction between free and bonded labour of

18. Breman, Labour Migration and Rural Transformation; see also Robb, "Introduction".

19. Idem, Patronage and Exploitation; Thorner, Land and Labour in India, pp. 63-64; Thorner,

Shaping of Modern India.

20. Mundle, Backwardness and Bondage; Prakash, Bonded Histories.

2I. Patnaik, "Introduction", p. I4; see Idem, Reflections on the Agrarian Question, p. 28.

22. Brass, "Unfree Labour and Capitalist Restructuring", p. 56. 
the doctrinal zeal with which he has infused it. ${ }^{23}$ My own opinion continues to be that earlier forms of bondage in agriculture have disappeared but that they have not always been replaced by free labour. I have taken as an example the recruitment and employment of an army of labour migrants in sugar cane cutting in south Gujarat, which is run on an industrial basis.

[...] a capitalist mode of production on the other hand by no means precludes certain forms of absence from freedom, emanating for example from the necessity to enter into debt. It also explains why there are certain features in the plight of the cane-cutters which, although serving new purposes altogether, are essentially those of pre-capitalist labour relationships. ${ }^{24}$

That which I have later termed neo-bondage has proved able to go handin-hand with capitalist labour practices. ${ }^{25} \mathrm{I}$ am inclined to agree with Ramachandran who, at the end of his report on fieldwork in Tamil Nadu, concludes that the trend is towards more free labour relationships although features of the earlier regime can still be identified in day-to-day practice. I tend to support his argument that a complex set of factors works towards the commoditization of labour power, towards impersonalizing the relationship between worker and employer, and towards establishing the freedom of a worker to sell his or her labour power to employers of their own choice. All being said and done, however, freedom to manoeuvre has many constraints.

The failure of industry to absorb the vast numbers of the agrarian unemployed as well as the interaction between the phenomenon of a surplus population and the pre-capitalist aspects of the village community cannot but have a profound significance for the socio-economic status of the manual worker in the village. ${ }^{26}$

This passage quite correctly links the social quality of agricultural labour to stagnation in the transition to industrial employment. Later in this paper I shall return to the problem of continuity and discontinuity of labour bondage, both in and away from agriculture and the village economy. Here, I suffice with observing that post-colonial literature saw the labour question one-sidedly in terms of industrialization and urbanization. The only connection made with the rural economy was to the effect that a labour surplus had accumulated, which would have to flow towards the economic growth poles. But did the rural masses, forced into mobility according to this conventional line of thought, meet the requirements set for a modern industrial proletariat?

\section{A DEFICIENT WORKFORCE}

The strong emphasis on the rural origins of the working class at sites of industrial employment dates back to the colonial era and constantly recurred

23. Brass, "Class Struggle and Deproletarianisation", pp. 36-37.

24. Breman, "Seasonal Migration and Co-operative Capitalism", p. I350.

25. Breman, Beyond Patronage and Exploitation; Idem, Footloose Labour.

26. Ramachandran, Wage Labour and Unfreedom in Agriculture, p. 262. 
in reports concerned with that period. It was coupled with the notion that early generations of factory hands refused to sever their ties with the hinterland. Characterization of the industrial worker as a peasant manque was a principal motif of the late-colonial Report of the Royal Commission on Labour in India. ${ }^{27}$ The received wisdom was that economic necessity had forced the migrants to leave their villages and that, while searching for work and income away from agriculture, they never relinquished the idea of returning home again. Rural people were said to show little interest in what the outside world had to offer and were only reluctantly prepared to leave their kindred and the village milieu.

Hunger, unemployment and boredom occasionally drove the ryot out of the village and into the city. Much more generally, the native village held him in spite of miserable living conditions. In his attachment to the village, he was influenced by several social institutions, among which caste, the joint family, early marriages, and the diversity of languages were the most important. ${ }^{28}$

The image of an unwilling army of migrants approaching the factory gates willy-nilly is further elaborated in the equally negative assessment of the lack of enthusiasm with which this influx of workers subjected themselves to demands of the industrial regime. Their disappointing quality was shown by a low and slovenly work pace (loitering was an ever-recurring complaint), the ease with which they changed jobs, and the high degree of absenteeism which was linked with their equally perfidious habit of returning to their villages whenever they felt like it and of staying away indefinitely. At heart they are still peasants, was the lament voiced by a long series of private and public commentators. Criticisms cumulated into the verdict that labour discipline was seriously defective. Experience over many years gave rise to the suspicion that this was by no means a transitory phenomenon and could not be regarded as a temporary handicap that would gradually be corrected as workers became accustomed to the regime.

This image, commonly held during the colonial era, acquired new impulse in social science literature which described the course of the modernization process that started in the early I950s in such a way as to cause doubt regarding the capability of the mass of non-Western peoples to internalize the type of behaviour that met the characteristics assumed by an industrial way of life. Like Kerr, Feldman and Moore saw industrialism as implying a set of conditions that needed to be met before the process of economic transition could be considered to be complete and successful. They considered that the worker who shows commitment needs little supervision and has more self-discipline. His behaviour is reasonably predictable and need not be enforced through external checks and sanctions. These authors also raised the more general question of how, as economic develop- 
ment progresses, the obstacles that hamper the quantity and quality of labour supply could be overcome. ${ }^{29}$ Myers was among those who discussed this question and the assumptions on which it was based more specifically with regard to the Indian situation..$^{30}$ Ornati went so far as to speak of a dislike for factory work. He showed agreement with the opinion that the industrial worker, in the proper sense of the term, was lacking in India. More than anywhere else, violations of industrial discipline, including damage to goods and machinery, protracted inertia and other forms of "unsuitable behaviour" needed to be punished with fines. In Ornati's view, shows of defiance were caused by the worker's evident inability to adapt himself to the working conditions that are inherent to life in industry. "Occasionally, the worker leaves the factory not to return to the village but to rebel against being forced into what might be called the 'factory norms': time discipline, the limitation on leisure, the confines of the machines, the toil of learning, and the like. ${ }^{{ }^{31}}$ Their peasant background made it understandable why they preferred the more irregular and more risky existence as self-employed, which also required less self-discipline. The "peanut entrepreneur" had to cope with far greater economic uncertainty but, in Ornati's view, his life was more attractive on social and psychological grounds.

In 1958, under the auspices of the American Social Science Research Council, a conference was held in Chicago on how to motivate labour to perform noncustomary tasks as a precondition for economic growth. Moore and Feldman were the editors of Labor Commitment and Social Change into which papers presented at the conference were bundled. "Commitment involves both performance and acceptance of the behaviors appropriate to an industrial way of life", was their succinct definition of the topic in their introduction. ${ }^{32}$ In his contribution Kerr makes a distinction between successive stages of involvement, culminating in the willingness to conform permanently, completely and unconditionally to the demands of the new mode of production..$^{33}$ At the same conference Moore embroidered further on this subject by specifying, with regard to India, "the web of rules" which needed to be fulfilled before one could speak of a stable and dedicated labour force:

[...] when workers no longer look on their industrial employment as temporary, when they understand and accept the requirement of working as part of a group in a factory or other industrial enterprise, and when they find in the industrial environment a more adequate fulfilment of personal satisfactions than they enjoyed in the village or rural society. ${ }^{34}$

29. Kerr, "Changing social structures"; Moore, Industrialization and Labor; Moore and Feldman, Labor Commitment and Social Change.

30. Myers, Labor Problems.

3I. Ornati, Jobs and Workers in India, p. 47.

32. Moore and Feldman, Labor Commitment and Social Change, p. I.

33. Kerr, "Changing Social Structures", pp. 35I-352.

34. Myers, Labor Problems, p. 36. 
Even when measured only against the first of these criteria, according to the author, Indian factory workers were at best only partially committed. They were keen to have fixed employment, but had no scruples in deserting the job, unexpectedly and unjustifiably, in order to visit their home villages. This was best illustrated by the high degree of absenteeism. Like many others, Myers referred to the accurate and up-to-date body of statistics, published in the Indian Labour Gazette and the Indian Labour Yearbook, on the high percentage of workers who did not report daily for work. "In a sense, these Indian workers want to have their cake and eat it too: they are partially committed to factory jobs in that they regard them as more or less permanent which can be interrupted (but not lost) by periodic visits to the village." ${ }^{35}$ To defend themselves against such unpredictable desertion, the factories set up a reserve pool of labour on which they could draw whenever necessary to meet their strongly fluctuating requirements. Each factory maintained such a stock of casual workers. Continuing along Myers's line of thought, James argued that the emergence of these badlis demonstrated the common sense and leniency of the employers. Understanding that their workers found it difficult to adjust to an industrial existence, and drawing a lesson from long experience, they had purposely refrained from harnessing their permanent workforce too tightly. ${ }^{36}$ But high absenteeism was not the only reason why Myers placed Indian factory workers so low on the ladder of commitment. "Commitment to industrial employment implies more than the presence of workers on the job, however. It involves also their acceptance of industrial discipline and the performance of tasks under supervision. ${ }^{{ }^{37}}$ The self-discipline demonstrated by committed workers made them able to meet the industrial tempo which machinery forced on its operators. Feldman and Moore remarked that machine pacing and rhythm impart an increased rigidity to the structure of work activities. In addition, workers are unwilling to accept managerial authority, in particular control exercised over them by shop floor supervisors. Their resistance to interaction with machinery might be due to their rejection of the property relations that form the basis of this industrial mode of production. After all, factory workers operate machines that belong not to them but to others. It then has to be asked whether the workers are familiar with ownership notions and, more importantly, whether they behave accordingly. ${ }^{38}$ If not, should the covert or overt demand for redistributing the industrial means of production be seen as expressing a lack of engagement?

It is interesting to note that in discussions on these issues, narratives regarding lack of commitment change effortlessly into complaints about lack of discipline. That which is initially explained as non-internalization is

35. Ibid., p. 45 .

36. James, "Casual Labor Problem", pp. Ioo, IO4.

37. Myers, Labor Problems, p. 53.

38. Feldman and Moore, "Commitment of the Industrial Labor Force", pp. 19-26. 
turned around and given the tenor of employers' failure to gain an adequate grip on the behaviour of their subordinates. Loitering, frequently leaving the machines without permission to get some fresh air or to smoke a cigarette, is the most innocent example of this behaviour which borders on sabotage. A more extreme variation of labour indiscipline is the physical violence used against members of the higher or lower factory management such as timekeepers. ${ }^{39}$ In the same breath the author refers to strikes that degenerate into gheraoing the company offices. In such cases the warning seems to be forgotten that commitment to industrial labour and commitment to managerial practices should not be confused the one with the other. Rather than insufficient engagement, unrest and other actions can equally and perhaps more justifiably be described as symptomatic of the opposite. ${ }^{40}$ This brings me to conclude that adherents of the lack-of-commitment thesis usually restricted themselves to pointing out this lack in the activities of the working class. Kerr is quite explicit about this bias and adds that such a handicap does not apply to the managerial elite. ${ }^{4 \mathrm{r}}$ His diagnosis contrasts squarely with the findings of research held in a west Bengal factory to the effect that supervisors charged with disciplining the workers did not themselves have the necessary discipline to fulfil their task properly..$^{42}$ More in general, I contend that what Myers and others describe as labour problems in India's industrialization are presented by them primarily as problems caused by the labour force. This biased approach detracts from consideration given to the problems experienced by a very large part of the industrializing population. The emphases placed by Myers in particular seem to me to be connected to the manner in which he carried out his research. In compiling the empirical data on which his analysis is based he restricted himself principally to discussions with management. His Indian research associate was assigned to report on trade unions. In addition to 125 officials in forty-nine enterprises, Myers spoke to leaders of employers' organizations and trade unions, government officials, academics, and representatives of international agencies (including the ILO and American technical missions). Did Myers meet any workers? It seems very doubtful, unless they took part in any of the sixteen group discussions held with "mill technicians, labour officers, union leaders and management groups" ${ }^{43}$ It would be difficult to label these ventures as shop floor investigations.

\section{REJECTION OF THE COMMITMENT CONCEPT}

Morris was one of the first to qualify the alleged shortcomings in industrial labour behaviour as misleading and premature. His historical study of

39. Myers, Labor Problems, p. 48.

40. Moore and Feldman, Labor Commitment and Social Change, p. 4.

4I. Kerr, "Changing Social Structures", p. 358.

42. Chattopadhyay and Sen Gupta, "Growth of a Disciplined Labour Force", pp. I209-I2I6.

43. Myers, Labor Problems, p. xvi. 
labour and the growth of cotton mills in Mumbai, supplemented by a brief and less in-depth research into the development of the Tata Iron and Steel Company (TISCO) in Jamshedpur, brought him in many respects to conclusions that were diametrically opposed to the image that had been current even in the colonial era and which, in post-colonial years, was further endorsed in an expanding literature on the process of economic growth. Morris started by refuting the thesis that urban industry had ever suffered from lack of labour. In all phases of industrial expansion it had never been difficult to recruit workers for the textile factories, although the distance that needed to be covered increased over time. Simultaneously, however, a working class had evolved which closely identified with Mumbai's industrial sector and had renounced its roots in the rural milieu. ${ }^{44}$ The author also rejected the notion that a rigid social ideology prescribed a bond with traditional institutions and with the village in particular. Then how did Morris explain the on-going mobility which continued to characterize a hefty part of the urban migrant army? To understand this floating behaviour, according to Morris, it was first necessary to distinguish between large-scale and small-scale industries and between enterprises that produce the whole year through or only seasonally. In other words, circulation between city and village was caused by the nature of economic activity rather than by the ingrained habits of workers. ${ }^{45}$ And finally, Mumbai's cotton mills were able to obtain the workers that they wanted, employed on a temporary basis and able to be dismissed without notice, while productivity remained low due to lack of investment in training and management.

These practices made it possible to use very large amounts of minimally trained labor, precisely the sort that was easy and cheap to obtain in Bombay. But the work schedule also made it necessary to employ enough labor to permit workers to take breaks while the machines were running, to develop what in effect amounted to an informal shift system [...]. There is no question that employers could have initiated a tighter and more precise system of labor utilization and discipline had they so wished. But such an approach would have required more expensive supervision than could be obtained from the jobbers [...]. ${ }^{46}$

An industrial working class was thus formed without the employers having to face any major problems. Morris did object, however, to the tendency to emphasize the psychological aspects of labour discipline, advocated among others by Kerr and Myers. Industrial work did indeed subjugate the workforce to fairly rigid rule-by-the-clock, but in his opinion there was no question of any acute break with the manner of employment to which land workers were accustomed. Germane in this connection is his remark that the majority of factory workers had no contact with machines. ${ }^{47} \mathrm{He}$ also

44. Morris, "Labor Market in India"; Idem, Emergence of an Industrial Labor Force.

45. Morris, "Labor Market in India", p. 175.

46. Morris, Emergence of an Industrial Labor Force, p. 203.

47. Morris, "Labor Market in India", p. I88. 
dismissed the suggestion that labour unrest could indicate lack of commitment. In his view, willingness to strike meant just the opposite: it expressed progressive adaptation to the industrial way of life.

The sociologist Lambert who, in 1957, charted the origins and identity of the workforces of five factories in Pune, stated in the introduction to his book that he had found no confirmation of the "recruitment-commitment problem" ${ }^{48}$ Some of the workers he interviewed (a stratified random sample of 856 chosen from a population of 4,249) said that they would probably return to the countryside when their working lives had finished. The researcher found this surprising in view of the fact that one-third of his respondents had been born in Pune and a non-specified percentage in other urban localities. The majority of the workers were certainly not migrants who had only recently left their villages. There was evidence of such largescale commitment to factory employment that Lambert concluded that three-quarters of his respondents belonged to the committed category of workers, at least in the sense understood by Moore and Feldman. ${ }^{49}$ Lambert made it quite clear, however, that he found little advantage in using this modish concept. In another fashion he nevertheless showed his doubt regarding the transforming character of the industrial-urban system in which his respondents were embedded. The transition from tradition to modernism in Indian society had been very incomplete, in his view. Factory organization showed features deriving from social institutions that originated in village life and in the caste hierarchy. Lambert referred here to the jajmani system which granted members of the local community the right to a job and a livelihood. The patron was not allowed to cancel the multifarious relationship one-sidedly, even when the client's performance left much to be desired. Transgression of this prescript could cause the patron to be boycotted by his caste. According to Lambert, employer-employee relations in the factory are based on the same principle. The worker regards his job as his property and assumes the existence of an accord which the employer is unable to terminate on grounds of unsatisfactory discipline and insufficient efficiency. As long as the worker approaches his boss as client, behaves towards his boss deferentially, and meets all sorts of obligations that have nothing to do with the level or quality of his working performance, continuation of his employment is a justifiable expectation and, in the last instance, self-evident. As far as patrons are concerned, their clients might preferably show rather less commitment. In the early phase of the industrialization process the employer could only escape a claim to social security by using labour contractors and jobbers who profited from a constant rotation of workers. When those practices disappeared, the factory job

48. Lambert, Workers, Factories and Social Change, p. 6.

49. Ibid., pp. 83-84. 
became a more permanent form of property. Employers reacted to this limitation of their powers to discipline, select or dismiss their workers, by making it more difficult to obtain fixed employment. They did so by forming a pool of reserve workers who were available when needed and who had far fewer rights than permanent employees. ${ }^{50}$ The author concluded by stating that the transformation towards a modern society, the conversion of Gemeinschaft into Gesellschaft in India, is still a matter for the distant future.

Far more nuanced was the picture that Sheth drew of labour and labour relations in a modern industrial enterprise in a medium-sized city in west India, which he gave the fictitious name of Rajnagar. The author is a sociologist and the report of his fieldwork, carried out in 1956-58, was not published until much later. ${ }^{\text {II }} \mathrm{He}$ found no confirmation for the hypothesis taken as his point of departure, namely, that Indian traditional institutions such as the village community, the caste system and the joint family, had obstructed progress towards industrialism based on machine technology. According to Sheth, that which Moore, Kerr and others had designated an industrial society was actually an ideal-typological construct for a great variety of social formations that had become reality without approximating that prototype. It was equally impossible to reduce the pre- (or non-)industrial society to one uniform model. Sheth followed this negation of any extreme black and white contrast by stating that the introduction of new technology did not necessarily preclude continuity of the traditional social system. In his view it was incorrect to posit, as Moore had done earlier, that sluggish economic development was to be blamed on the tenaciousness of traditional social patterns which emphasized fixation rather than mobility. ${ }^{52}$ The commitment concept actually represented further operationalization of that line of thought, but for his own field of study Sheth found this term of doubtful relevance. In his opinion, there was no rupture between industrial relations and the wider social environment. Factory managements applied ascriptive and particularistic norms in their dealings with the workforce, not incidentally but purposefully. Did that not accord with the manner in which personnel policy was implemented by Japanese industry? Between the traditionoriented social life of the worker and his work in the factory that was based on rationality, compatibility ruled rather than conflict. "In Oriental [pseudonym for the researched enterprise] one finds a coexistence of the two sets of values and neither seems to hinder the operation of the other." ${ }^{\text {\$3 }}$ In its analysis, Sheth's study showed affinity with the tenor of the research reported on by Lambert. Both record that industrial employment does not

50. Ibid., pp. 9I-94.

5I. Sheth, Social Framework.

52. Moore, Industrialization and Labor, p. I24.

53. Sheth, Social Framework, p. 203. 
cause a watershed in the worker's attitude and behaviour. Neither Lambert nor Sheth, however, have supported their arguments by discussing the social life of the workers or the way in which they spend their incomes and leisure time outside the factory gates. In view of the conclusions that they draw, this would have been a logical sequel to their investigations. Sheth pointed out that his modus operandi differed from that of Lambert. The latter concentrated on presenting actual data obtained on the basis of a questionnaire and gave no attention, as did Sheth, to analysing inter-personal relations in the factory. Another difference between the two which I find rather striking is that, even more than Lambert, Sheth failed to give the pool of casual labourers (in both cases about one-fifth of the total factory workforce) the strategic significance that that industrial reserve army deserved. ${ }^{54}$

Numerous authors, from various sides and for differing reasons, have pronounced categorically against the commitment thesis. Sharma did so on the basis of socio-psychological research in 1965/66 in which he studied the attitudes and behaviour of labourers employed by a car manufacturing plant in Mumbai. His study was inspired by ideas proclaimed by Ornati, Kerr, Moore et al. To test them out, he undertook 262 in-depth interviews to ascertain the level of commitment to each of the many aspects of work as well as non-work experience of his respondents. The profile compiled by Sharma shows that his respondents did not represent any cross-section of the surrounding population. The factory appeared to prefer educated workers over the non-educated, urban-born over the rural-born, and workers with industrial experience over those with no experience or with a background in non-industrial occupations. ${ }^{55}$ With regard to absenteeism, the author noted that workers of rural origin had a better attendance record than their colleagues who had grown up in the city, and that trade union members were less likely to absent themselves than were non-members. His findings were contrary to the assertions made by adherents of the commitment thesis. In a more general sense, Sharma's study also failed to confirm the conventional image of the industrial worker as someone still rooted in the countryside and in agriculture who has difficulty in breaking those ties. There was apparently no evidence of alienation and anomie to which, according to the stereotype, the labourer would fall prey in his new environment, with lack of discipline as an important symptom. Sharma concluded that:

[...] traditional Indian culture appears to present no serious obstacles to the workers in either accepting factory employment or in becoming committed to industrial work. Moreover, the commitment of workers seems to be influenced not by their traditional backgrounds but by work technology within the factory. ${ }^{56}$

54. Ibid., p. 203.

55. Sharma, Indian Industrial Worker, p. I4.

56. Ibid., 48. 
This quotation is significant in that it draws attention to the fact that factory workers were not a uniform type. They showed numerous variations, differing the one from the other according to the nature of the industry, the technology used and, last but not least, the demands regarding training and skills made on the workers at their moment of entry. The diversity in modes of employment between more and less technologically-advanced factories obviously had consequences for the social composition of the workforce and also helped to determine the worker's attitude towards his work and employer.

Holmström, finally, based his monograph on industrial workers on more anthropological methods of data collection. The fieldwork that he carried out in 197I was localized in Bangalore and concentrated on workers in four factories, two in the public sector and two in the private economic sector. His research did not focus on industrial organization and industrial relations within it, but was concerned primarily with the residential milieu to which workers retreated outside working hours. The author based his findings on case studies of IO4 workers, selected from a far larger population, and making allowance for obvious criteria such as educated/uneducated, young and old, members of diverse castes, etc. ${ }^{57}$ His point of departure was that the significance and impact of urbanization should not be confused with those of industrialization and that, with regard to the latter, it was senseless to assume a simple linear dichotomy between tradition (rural-folk society) and modernity (urban-industrial society). The principal questions that inspired his research were: firstly, the social identity of the factory workers and what distinguished them from the majority of city dwellers who had not found access to modern and large-scale industrial enterprises. Secondly, how members of this industrial vanguard thought about their own situation and, more in particular, about their work and career. Holmström rejected the commitment requirement for his research group as being essentially immaterial. "Many forms of organization are probably compatible with industrialization, or the failure to industrialize; and the forms actually found in industrial countries probably depend as much on historical circumstances as on the technical requirements of the industrial process. ${ }^{n 8}$ The author does not give an unequivocal answer to his own question of whether members of the industrial vanguard being shaped in India considered that they belonged to a labour aristocracy. Rather than confirming or denying this, Holmström advocates that the question be broadened in the context of a more comprehensive analysis that would include other segments of the labouring landscape. The author himself put this idea into effect in a later work..$^{99}$

57. Holmström, South Indian Factory Workers.

58. Ibid., p. I44.

59. Idem, Industry and Inequality. 
In an overview published in 1977, Munshi discussed the arguments that have been expressed over time by supporters and opponents of the commitment theory. His critical discussion is followed by a devastating judgement on the utility of the concept in all its aspects. ${ }^{60}$ The author refused to adopt the counter-argument which would have forced him to prove the industrial commitment of the Indian worker. To do so would demonstrate the relevance of the theory on which it was based and that, in his opinion, was out of the question. Scruples of a methodological, conceptual and empirical nature have already been discussed extensively. Munshi rejected the dualism demonstrated by advocates of the concept by elevating modernism and tradition into static and opposite poles. The assumption, whether explicit or not, was that industrialization would follow the pattern that had originated in the west. Deviations from that model were said to be defects caused by the inadequate cultural equipment of the latecomers to the once established development paradigm that was claimed to have universal meaning. Another prejudice, ideological in nature, was that in the literature under discussion, failure to realize the appropriate transition to "the modern economy and society" was projected onto the specific inability of the working masses to meet demands dictated by the logic of industrialism. In that line of thought, the transformation was also attributed to external forces, in particular to the strategic significance of a management style attuned to industrial relations in American industry. ${ }^{61}$ In his later publication, Holmström summarizes this approach as follows:

Foreign writers, and some Indians, wanted to find the formula for successful industrialization, the ingredients missing from the traditional society which must be added to make India an industrial country: entrepreneurship, efficient management, changes in social values, "achievement-orientation" or a committed labour force. The problem of supplying the missing ingredient or ingredients was believed to be common to non-industrial countries which lagged behind, at various points, on the great highway of development marked out by the west and Japan. ${ }^{62}$

One difference with the dualism doctrine as shaped in colonial times ${ }^{63}$ was that the new variant at least acknowledged that non-Western peoples did indeed have the ability to develop according to the given example. However, this concession was accompanied by the warning that it would be a lengthy process because industrial mentality could not be expected to become internalized until much later than the initial generation of industrial workers.

Ram was one of the first to attempt to rise above the discussion between adherents and critics of the commitment theory by drawing attention to

6o. Munshi, "Industrial Labour in Developing Economies".

6I. Ibid., p. 82

62. Holmström, Industry and Inequality, p. 28.

63. Higgins, "The Dualistic Theory' of Underdeveloped Areas". 
ways in which the capitalist work process manifested itself in India. Its specific nature, she argued, was expressed in the interconnection between rural and industrial labour. In the coal and iron mines of west Bengal, Madhya Pradesh and Orissa, for example, workers were not even given the opportunity to cut their ties to their village of origin. This also applied essentially to migrants who found more permanent employment but were able to support only themselves in the new location, being denied both accommodation and an income that would be sufficient to enable their family members to accompany or join them. "It allows employers to transfer the costs of reproducing and maintaining workers' families, and even of providing for the worker himself in times of illness and old age, on to the villages." ${ }^{\circ 4}$ Significant in this connection is Ram's observation regarding the extremely unequal distribution of work among the sexes which characterizes increased mobility. The Indian pattern of industrialization and urbanization has in fact largely been based on women's exclusion from industrial employment. Ram quite correctly posits that theoretical literature had so far given too little attention to the very biased gender composition of India's industrial economy.

\section{FACTORY WORKERS AS DOMINANT CLASS IN THE URBAN ECONOMY}

The growth of India's modern proletariat was largely an urban phenomenon. The new towns and cities that arose in various parts of the country, next to the already existing urban centres, became the sites of a great diversity of industrial enterprises. The economic policy adopted in postIndependence years was intended to bring about an industrial infrastructure with a far broader base than had been established under foreign rule, or had even survived from pre-colonial times. The jute and cotton mills had long been of vital significance to Calcutta, Mumbai and Ahmedabad. Here and elsewhere the manufacture of clothing and footwear was supplemented by a broad range of consumer goods, both for daily sustenance and for more durable use. Of much more recent origin was the emergence of heavy industries in the public sector of the economy, the manufacture of iron and steel in particular, for the production of capital goods, e.g. machine and construction workshops, petro-chemical enterprises, cement factories, the manufacture of cars and other forms of transport, military equipment, shipbuilding, etc. The second Five-Year Plan, implemented in 1956, prioritized the expansion of the industrial infrastructure. Labouring in state managed enterprises gave a distinct character to this part of the industrial workforce. The benefits included security of employment and access to social policies (housing, health and education) which were often denied to workers in

64. Ram, "Indian Working Class and the Peasantry", p. I82. 
private enterprises. The fair deal enjoyed by public sector personnel became a logical reference point in collective action efforts to improve the labour standard for industrial workers at large. The relations of production initiated in government controlled industries were conducive in dignifying labour. The 1969 Report of the National Commission on Labour elaborated on the major features of this new type of factory worker: strongly anchored in the urban milieu, originating in the petty bourgeoisie, equipped with some education and, finally, showing a noticeable degree of social mobility.

The social composition of labour is undergoing a change. Labour is not restricted to certain castes and communities. Apart from the fact that caste and occupation have always inter-acted and the relation between the two has been "elastic" in our society, social mobility today accounts for the emergence of a mixed industrial work force. While in traditional industries this change is slow, one cannot escape noticing it in sophisticated employments such as engineering and metal trades; oil refining and distribution; chemicals and petro-chemicals; machine tools and machine building; and synthetics and in many white-collar occupations. The background of the intermediate and lower cadres in the latter industries is overwhelmingly urban: their level of education is higher. They come from middle or lower middle classes comprising small shopkeepers, petty urban landlords, lower echelons of public service and school teachers and professional groups. They have a pronounced polyglot character. ${ }^{65}$

This portrait will be detailed first in terms of recruitment and mode of employment. The social profile that characterizes this category of workers, together with their lifestyle, will then be discussed.

The workforce which, according to the familiar cliché dating from colonial times, flowed straight from the villages to the factory gates, had little if any direct contact with management. Workers were recruited by jobbers who were frequently also charged with control on the factory floor. In such cases, the functions of recruitment and supervision were embodied in one and the same figure. The middleman was sometimes also responsible for housing and feeding the gang of workers taken on by him. The gap between demand and supply that had to be bridged physically, economically and socially was so crucial that the jobber is not without justification said to have been the midwife of the early phase of India's industrialization process. One of the first changes to occur, starting around the turn of the century, was the transfer of recruitment from the hinterland to the factory itself. Increasing pressure on subsistence sources at the bottom of the rural economy in particular, resulting from population growth and land alienation, caused an acceleration of the earlier flow of poor peasants and non-agrarian workers to the cities where industrial employment gained new impetus during and after World War II. In line with these dynamics, the room for manoeuvre

65. Government of India, Report of the National Commission on Labour, pp. 33-34. 
enjoyed by the jobber within the work hierarchy also disappeared. From being an intermediary between worker and management, leader of a gang of workers whom he had himself brought together, he became a foreman charged with implementing orders issued from above. "The hiring of workers is becoming the responsibility of the employment office, and the 'labour officer' is beginning to take over the welfare and service activities of the sirdar. ${ }^{166}$ The diminution of the jobber's role went hand in hand with the introduction of new set of rules which obliged major industrial enterprises to professionalize their personnel policies. After several transitional decades, the changing management style ultimately caused jobbers to disappear from the factories, as Papola concisely states. ${ }^{67}$

Other authors also show that, over the years, more impersonal selection criteria gradually became significant when taking on new workers. But does this mean that individualized traits derived from achievement, such as experience, training and social skills, have taken the place of the ascription-based qualities of applicants? The tendency in this direction, as Papola seemed to argue on an earlier occasion, ensued from the economic logic of the labour market, giving rise to the assumption that the employer allowed himself to be guided primarily by the question of who was the most suitable candidate to fill a vacancy. ${ }^{68}$ Papola thus dismissed the suggestion that subjective characteristics such as caste, religion, custom or tradition per se were of crucial significance in the search for work. Still, it was quite clear that personalized features continue to play a very large part. Recruitment through the mediation of members of the existent workforce helps to stabilize performance in the daily organization of production and thereby serves the interests of the employer.

Recruitment through present employees continues to prevail. According to the evidence before us, employers prefer this method to improve the morale of workers. In some companies, labour-management agreements specify entitlement to a percentage of vacancies to close relatives of senior employees. In a few cases, both the employer and the union maintain rosters of people so eligible for employment. Recruitment through advertisement is restricted mainly to supervisory and whitecollar employments and is being increasingly used to tap skilled labour. For occupations which do not require skills, an arrangement by which workers appear at the factory gate in the hope of getting employment still operates. ${ }^{69}$

The large-scale use of relatives, neighbours and friends in order to gain the favour of those who have jobs to bestow indicates the enormous discrepancy that still exists between demand and supply. The competition for access to regular employment in the factories is so great that applicants without any

66. Ornati, Jobs and Workers in India, p. 40.

67. Papola, "Labour Institutions and Economic Development", p. 27.

68. Idem, "Economics of Labour Market", p. I82.

69. Government of India, Report of the National Commission on Labour, p. 70. 
intercession and recommendation stand no chance at all. ${ }^{70}$ Some authors have linked the strength of such particularist mechanisms to the adaptation of traditional notions that prescribed support to kinsmen and other kindred as an act of loyalty and solidarity. Sheth was one of those who drew a parallel between the practice of patronage found in a medium-sized industrial enterprise and very similar manifestations of favouritism encountered in the social fabric of the wider urban society of which the factory was part and parcel. The time has passed when particularism was equated with an "earlier" or "lower" stage in an unilinear process of transformation on a continuum that eventually resulted in a type of civilisation said to be universalistic and globalized. A number of studies have drawn attention to the course followed by industrialization in Japan along a particularist pattern in which social identity was not lost but preserved and given shape in an adapted system of industrial relations. In similar fashion, the structural and cultural continuity of traditional India could be demonstrated in the transition to a modern industrial existence.

Without adhering to the superseded stereotype that the change from an agrarian-rural to an industrial-urban society could be nothing other than a copy of the path already taken in the West, other authors considered that the tenacity with which aid in obtaining work was given to family, caste or religious kindred should not be taken automatically as reflecting the sustained impact of "traditional" institutions. Such behaviour is rather common in situations of extreme scarcity and has to be understood as a more universal attempt to pressurize people more favourably placed to care for their kinsmen and mates and to do their best to help them in getting a job. In my opinion, it is against this background in particular that the meagre effect of "modern" types of labour mediation have to be understood. An analysis of a series of studies on industrial employment carried out in different parts of the country brought Papola to the following conclusion.

In over two-thirds of cases, the workers got information about the availability of jobs from friends, relatives and neighbours. Employment exchanges were the source of information to a very small extent, ranging from 1.5 per cent in Bombay to IO. 6 per cent in Coimbatore, though twenty per cent of the workers in Ahmedabad and twenty-five per cent in Poona had registered with the exchanges. Newspaper advertisements provided information about their jobs to I.5 per cent of workers in Bombay, 2.2 per cent in Poona and Io.6 per cent in Coimbatore. Jobs were secured on the basis of recommendation or introduction by friends, relatives and persons of the same region and caste, generally employees of the same factory, in sixty-seven per cent of cases in Poona and in sixty-one per cent of cases in Ahmedabad, Bombay and Coimbatore. Placement through employment exchanges accounted for two per cent of jobs in Poona and Ahmedabad. ${ }^{71}$

70. Holmström, South Indian Factory Workers, pp. 42-54; Ramaswamy, Work, Union and Community, pp. I8-19.

7I. Papola, "Labour Institutions and Economic Development", p. 27. 
These figures go a long way to explain why many factory workers attribute their access to the coveted arena of employment, in more veiled terms, to "coincidence" or "good luck". Such terminology quite incorrectly gives the impression of an unexpected windfall, a mere stroke of fortune. It is an euphemism for claims made on more fortunate fellows for help, an appeal for active intercession which usually is the rationale for their employment.

\section{MODE OF EMPLOYMENT}

In studies of industrial labour, researchers customarily and primarily direct their attention to workers permanently employed by medium to large-sized enterprises. Data are usually compiled on the basis of survey-type investigations. All employees of one or more establishments, or a sample thereof, provide information that is then recorded by field investigators in questionnaires or interview reports. Labour was also the target of earlier studies, but there was seldom personal contact with the workforce. As we have mentioned earlier, Myers kept his distance from the factory workers about whom he wrote $;^{72}$ Singer, who published an essay entitled "The Indian Joint Family in Modern Industry", based his findings on the family history of "nineteen outstanding industrial leaders in Madras City" ${ }^{73}$ The next batch of researchers did actually descend to the level of the workers, but even then it rarely went any further than brief one-off encounters, as is customary in such inquiries. Only those studies of a more anthropological nature gave the researcher a chance to penetrate the work and life milieu of industrial labourers more extensively and intensively. Uma Ramaswamy, for example, settled in an area populated by factory workers for the duration of her fieldwork. ${ }^{74}$ To my knowledge, however, no researcher has ever actually worked in a factory and reported thereon. Participatory observation, in that literal sense, is anything but a popular method of study. Also lacking is any documentation that originates among industrial workers themselves. Diaries, biographies or evidence in the form of oral history compiled in order to record the workers' own experiences, are almost unknown.

Research among factory workers has only rarely been extended to their activities in the actual workplace. Managers are often distinctly suspicious of the motives of the research and of the researcher. Not only does tangible benefit for the management appear to be lacking, but such alien busybodies might well have the intention of stirring up trouble among the workers. Similar prejudices may be found even among researchers. One source reports that questions regarding trade unions were avoided "[...] because

72. Myers, Labor Problems.

73. Singer, "Indian Joint Family", p. 433.

74. Ramaswamy, Work, Union and Community, p. I4. 
these excited the workers too much" ${ }^{75}$ Sheth is one of the few who have managed to move freely inside the factory walls and to ask whatever questions he liked. Thanks to a friendly contact, he was given permission by the owner to observe the daily work cycle in the factory at close quarters, on the understanding "[...] that I would stick to my academic business and would cause no trouble in the administration of the factory". Such authorization from high up, however, can also cause the researcher to encounter antagonism and distrust among the workers. This was Sheth's experience when, in talks on the shop floor, he was made to understand that transgression of the fairly tight limitations would not be tolerated by the bosses.

It is all very well. You are doing good work which may benefit us in the long run. But you don't know our employers' tactics! You will now write down your report and publish it. But I am sure that if your book contains anything against the interests of these masters, they will buy up all the copies of your book to prevent others from reading it. And they are so rich that they can buy any number of copies that you print. All your labour will then prove futile. ${ }^{76}$

The majority of studies base their glimpses of factory labour on encounters with employees outside the factory. This also explains why descriptions and analyses of the actual work process are still comparatively rare. Information regarding the work hierarchy within the enterprise is also very scanty. The social mobility mentioned in the 1969 Report NCL as an attribute of factory work, assumes the possibility of progressing towards a higher-ranking job. The complexity of industrial organization naturally varies with the nature of production and the technology used. The image presented by most studies, however, is one of little task differentiation. This impression agrees with Lambert's finding that, in the five factories that he investigated, seventy-five to ninety per cent of all workers were recorded as unskilled or semi-skilled. Moreover, the majority were still doing the same work that they did on first entering the factory. The unskilled category in particular, varying from one-third to three-quarters of the workforce, was distinguished by almost complete lack of mobility. ${ }^{77}$ In view of this evidence, it is hardly surprising that roughly three out of every five workers questioned by the author did not expect any promotion and apparently considered their present position to be as high as they would ever get. "Clearly, the bulk of the workers are 'fatalistic', at least so far as upward mobility in the factory is concerned." ${ }^{78}$

Careful perusal of these particulars leads us to suspect that the workers' assessment of the little chance they have to improve their position above all shows a strong sense of reality. Factory work has the aura of skilled labour, but in practice that applies only to a very limited degree. In many

75. Groenou, "Sociology of Work in India", p. 175.

76. Sheth, Social Framework, p. 8.

77. Lambert, Workers, Factories and Social Change, p. I3I.

78. Ibid., p. I85. 
enterprises, roughly one-quarter of the workforce belongs to the supervisory cadre and to maintenance staff. The former act as bosses on the factory floor; they do not take part in the production process but are charged with ensuring that work proceeds satisfactorily. The maintenance staff, on the other hand, carry out all kinds of tasks that make them indispensable although not important. As cleaners, guards, messengers or general dogsbodies they occupy the lowest ranks in the factory hierarchy. Between these two poles are the production workers, about three-quarters of the total workforce, who are split into two sections: "operators", who are assumed to be the skilled workers, and the subordinate "helpers" who function as their less skilled stooges and substitutes.

The progressive mechanization of production means that a higher percentage of workers than in the past now regularly or continuously handle machines, to the regime of which they have to subject themselves. This does not automatically mean that their performance becomes more skilled. Much of the work that has to be done is monotonous and makes no demands on a worker's competence as a craftsman. In that sense, access to factory labour may even result in loss of skills.

In view of the very limited prospects of occupational promotion within the industrial hierarchy, the question arises of whether factory employees try to realize their hopes of improving their position by changing their jobs. In contrast to the earlier stereotype of lack of commitment, the greater majority of Indian factory workers show extreme entrenchment. No less than Myers had ascertained that industrial workers tend to cling to their workplace at all cost. True, their absenteeism is of a high level, but horizontal mobility happens to be a rare phenomenon. In the USA, by contrast, such rotation occurs frequently. ${ }^{79}$

Lambert in particular elaborated further on this pattern of fixation, which resulted from a noticeably low degree of both vertical and horizontal labour mobility. He drew the conclusion that:

[...] most of the workers were interested in acquiring "permanent" property rights in a job and that this carries with it a notion of minimal quality of performance but not an internalized drive for continuously enhanced productivity [...]. Moreover, the general impression one gets in reading the literature on Indian factory laborers is that a factory job is a form of property to the worker and that he will seek to retain, but not improve it [...] the worker's status in the general society seems not to be increased by upward occupational mobility within the factory. ${ }^{80}$

While the early literature on the course of India's industrialization process mentions numerous and recurrent complaints about the lack of commitment with which industrial management had to cope, the problem defined

79. Myers, Labor Problems, p. 47; see also James, "Casual Labor Problem", p. IO3.

8o. Lambert, Workers, Factories and Social Change, p. 179. 
in subsequent studies was rather one of workers behaving as though they were clients who could not be dismissed by their patrons, i.e. their employers. According to this view, employees showed no inclination to perform adequately nor, in the course of time, were they willing to try and seek other jobs. Such an attitude was just as reprehensible as that of the uncommitted worker who refused to accept discipline and who played truant for the slightest reason or none at all. Conversely, the shortcoming of the over-committed worker was that he was "committed not only to industrial life but also to his particular occupation or his particular employer by training, by seniority rules, and by pension and welfare programs" ${ }^{81}$ This opinion has been contested, however, in other empirical studies. ${ }^{82}$ Fieldwork in an industrial neighbourhood of Coimbatore brought Uma Ramaswamy to a more sober assessment. She confirmed that workers who have been given permanent employment will fight tooth and nail against the idea that the jobs could be taken away from them.

Most workers expect to retire in the factories they first joined unless better opportunities present themselves elsewhere, which is unusual. They increasingly look at their jobs not only as a right but also as property to be passed on to their children through warisu [a hereditary transaction]. All these find their reflection in the low turnover in the workforce. ${ }^{83}$

The author states clearly, however, that this attitude should not be understood as referring to customary practice, neither is it caused by culturallydetermined characteristics. It is behaviour that issues from the attempt to achieve maximum security in a situation in which lack of permanent employment and consequent income is the rule rather than exception. "A secure mill job is the most coveted employment", she states briefly and to the point. Given the social condition of acute and continual scarcity, factory workers make every effort to secure their livelihoods, and if possible also those of their children and close relatives. However, their claim on the preservation of whatever comfort they have gained is driven by a defensive attitude. In my view it is a question of anxiety and of fear of falling back to a position of uncertainty rather than of indolence and a craving for property, a freeloader's mentality which acknowledges no obligations. In similar fashion, Holmström dismisses the suggestion that factory workers see their jobs as a form of property. ${ }^{84} \mathrm{He}$ considers that such a perception, insofar as it exists, is based on practices adopted by industrial management, combined with the need to let others in the direct circle of kinsmen and

8I. Kerr, "Changing Social Structures", p. 352.

82. Holmström, South Indian Factory Workers, pp. 139-I40.

83. Ramaswamy, Work, Union and Community, p. I45; for an updated statement see Ramaswamy,

"Wealth and Power Convert into Status".

84. Holmström, South Indian Factory Workers, pp. 139-I40. 
companions to share to some degree at least in the privileges and advantages that have been achieved.

The behaviour of factory workers in permanent employment is largely determined by the presence in most enterprises of a very substantial labour reserve. Lambert, as we have seen earlier, draws emphatic attention to temporary workers as representing a well-considered response by employers to "the problem" of workers who think that they enjoy indisputable rights once they have a permanent job. It is interesting to see that quite a few researchers devote their attention particularly to this peripheral category, and pay little if any heed to the role of the floating section of the industrial proletariat. The rapporteurs at a UNESCO survey of factory employment in various Indian states stated without elucidating that "the short-tenure factory workers and the non-factory workers had to be left out". ${ }^{85}$

Temporary workers are employed on a daily basis, but this does not always mean that the factory management is able to send them away again when they report at the stipulated time. Their more or less continuous involvement in the flexibly-organized work process, long after the duration of a reasonable trial period, is often unavoidable or may even be essential. The lack of any institutional pressure sanctioned by a formal work contract, however, gives employers at least the freedom to minimalize conditions of employment. Against this background it is easier to understand why, in my own fieldwork in south Gujarat, I repeatedly encountered people who had worked for the same boss on a temporary basis for more than ten years, without ever giving up hope of eventually being rewarded with a permanent job in return for their "loyalty".

The size of the labour reserve varies according to the nature of the enterprise. In the five factories studied by Lambert, ten to twenty per cent of the workforce belonged to that category. Sheth reports that in the industrial establishment of his research almost one-fifth of all employees were temporary. In addition, there was a category of casual workers who were called upon and dismissed according to the need of the moment. Two subcontractors were charged with hiring these outsiders. Each morning the manager reported how many extra workers would be needed for that particular day, and the two labour contractors took care of their admission at the factory gates. On average they numbered to seventy or eighty men, representing another ten per cent of the factory's workforce. The contractors were paid piece rates. Neither they nor the gangs working under them appeared in the factory's administration. These middlemen were paid a round sum, from which they first deducted their own generous earnings before paying their teams. This reserve labour pool, kept floating and completely without rights, was not only called upon for all kinds of odd jobs,

85. Versluys, Prabhu, and Vakil, Social and Cultural Factors, p. 7. 
such as the loading and unloading of goods, but also to take the place of any regular labourers who had not reported for work. ${ }^{86}$

Holmström's study of industrial employment in Bangalore revolves around the idea that those admitted to factory employment had crossed the threshold to a secure existence. The contrast with the endangered life outside the mill became paramount. "Once inside the citadel, with a job to fall back on, improving one's qualifications and getting promotion becomes a gradual process, a matter of more or less, faster or slower progress, rather than simply of having a permanent job or not having one. ${ }^{\text {" } 7}$ In my opinion, this viewpoint shows too little consideration for the considerable and often lasting gap between temporary and permanent workers. Holmström seems to suggest that passing from the former to the latter category is in most cases nothing more than a matter of time and patience. "Even educated Brahmans will take unskilled casual factory work in the hope of permanent jobs. Once inside the citadel, a man can look around for alternatives, if he wants. ${ }^{n 8}$ His suggestion of upward mobility as a rather common career pattern is not confirmed by several other studies. In fact, temporary workers often get no further then the bottom of the work hierarchy. This reserve pool, although better off than the labour nomads beyond the factory gates, can make no claim on the secure conditions of employment enjoyed by permanent hands. They are usually if not always given the most lowlyvalued and unskilled chores available. Even when their work is no different to that of tenured employees, they are paid far less. ${ }^{89}$ In the four factories in Pune on which he concentrated his investigations, Lambert noticed a tendency to lengthen the term of temporary employment. "[...] it does appear that the average time spent in non-permanent status is increasing in all the factories, and that the two older companies using the badli system have a non-permanent labor pool that is tending to become stabilized". ${ }^{\circ}$

I would be inclined to make that conclusion dependent on fluctuations in the industrialization process over time. It seems reasonable to assume that, during periods of rapid growth when existing factories expand their production and new ones are opened, permanent employment becomes more quickly and easily available. Exactly the reverse holds in a period of industrial recession. It was probably no coincidence, therefore, that Uma Ramaswamy, who undertook her Coimbatore fieldwork in $1977 / 78$ when the local textile industry had just gone through a decade of massive retrenchment due to mill closures and strongly reduced production, came across a residual category of workers who had been registered as temporary hands sometimes for over a dozen years. In addition to the fact that they were

86. Sheth, Social Framework of an Indian Factory, pp. 56-57.

87. Holmström, South Indian Factory Workers, p. 4I.

88. Ibid., p. 137.

89. Lambert, Workers, Factories and Social Change in India, pp. 99-100.

90. Ibid., p. IO2. 
much cheaper, factory management expected them to be far more tractable. The vulnerability of their position was described by a permanent worker.

There are about seventy temporary workers in our mill. They were made to give their signatures on blank sheets before being taken for work. They have to report for work ten minutes before the others and are sent out ten minutes after the shift is over. The idea is to prevent them from mixing with permanent workers. Management fear that association with permanent workers might cause discontent in them. If a temporary worker is found sitting at the back of my cycle, he would be immediately denied employment. The blank sheet with signature would be used to write out his resignation. ${ }^{91}$

While making allowances for the interchange of good times with bad and for major branch-specific variations, it must be said that the transition to an industrially-based society has been far more tardy and erratic than had been hoped and predicted half a century ago. Labour productivity is still at a low level. Pro-business management publications attribute this to the militant attitude adopted by workers and by trade unions that tend to be aggressive in defending the entrenched interests of their members. Taken together with the numerous holidays and other days off, according to some sources, this means that a quarter to almost half of all days per year are lost in doing nothing. As a result, factories are brought to a standstill far more frequently than in the industrialized parts of the world, according to the presidential address given to the Indian Society of Labour Economics in $1983 .^{92}$

From an entirely different perspective, low productivity could be blamed on the stubborn refusal by factory owners to invest sufficient capital. Rather than introducing technological improvements with which to increase productivity, the emphasis is on making the labour process more onerous. Women are frequently victimized by this strategy. Fearing a loss of income, they are prepared to do work that is customarily carried out by men, to allow themselves illegally be included in night shifts, and to work overtime without extra payment. ${ }^{93}$

The skilled factory work associated with industrial employment has until today remained the domain of only a tiny portion of the total workforce within the sector. In recent times surplus labour, which has acquired enormous proportions in the countryside, has sought en masse for work away from the village and from agriculture. Those of the surging army of migrants who manage to reach the urban economy for shorter or longer periods, are able only to a very limited degree to penetrate to the enviable but strongly protected bastions of secure employment in the factories. As we have seen, even such access by no means always provides, whether immediately or in

9I. Ramaswamy, Work, Union and Community, p. 2I.

92. Papola et al., Labour, Employment and Industrial Relations in India, pp. 294-325.

93. Ramaswamy, Work, Union and Community, p. 23. 
the future, the longed-for permanent job and related security of existence. Nevertheless, it is this more fortunate category, more influential than might be supposed from its size and status, which has become of vital significance as a truly dominant class in the urban-industrial landscape. What are the principal social characteristics of this elite among the working population?

\section{SOCIAL PROFILE AND LIFESTYLE}

In contrast to earlier notions that portrayed the factory labourer as a rural migrant only recently arrived in the city, the majority of studies show that many if not most workers are men and women who have lived in the city or its immediate environs for many years, if not since birth. ${ }^{94}$ A great many of the masses who have only recently settled in urban locations would be only too grateful to be considered for factory employment, but they lack the experience and contacts needed to compete for such work. The conditions that E. A. Ramaswamy found in the mid-rg7os in his research in Coimbatore were by no means exceptional. "The textile industry in Coimbatore is near saturation from the employment point of view. Even with the creation of additional capacity, jobs are too few in relation to the number of aspirants, particularly considering the low skill requirement." ${ }^{\text {"s }}$ The same sources observe that the percentage of literates among industrial workers in large-scale enterprises is quite high. Although lower education, let alone a higher grade, is not really essential for unskilled work, practice shows that the ability to read and write is a minimum qualification for acceptance even as a temporary hand. In the course of time educational standards for acceptance have been further upgraded. Candidates who lack a secondary school certificate are no longer considered for selection. ${ }^{96}$

Conventional opinion holds that the first to report for work in the modern urban industries were the landless and land-poor farmers who had led a poverty-stricken and threatened existence in the countryside. ${ }^{97}$ The social complement to their economic vulnerability was their membership of low or even the lowest castes. As urban industrial employment gained in respectability, higher castes also began to show interest, according to Myers. ${ }^{98}$ Morris was one of the first to reject this viewpoint. He dismissed the idea, which can be traced back to Weber, that a significant part of the

94. See Lambert, Workers, Factories and Social Change in India, p. 7; Sheth, Social Framework of an Indian Factory, pp. 79-82; Holmström, South Indian Factory Workers, p. 28; U. Ramaswamy, Work, Union and Community, p. I2.

95. Ramaswamy, Worker and His Union, p. I75.

96. Holmström, South Indian Factory Workers, p. 38; Ramaswamy, Work, Union and Community, p. 20.

97. E.g., Buchanan, Development of Capitalist Enterprise in India, p. 294; Ornati, Jobs and Workers

in India, p. 29.

98. Myers, Labor Problems in the Industrialization of India, pp. 39-40. 
emerging industrial proletariat stemmed from "declassed and pariah castes" of rural origin. In his study of labour in Bombay's cotton mills, Morris defended the thesis that caste was not a relevant, let alone primary, criterion in the recruitment of workers, or that members of untouchable castes were discriminated against. ${ }^{99}$ More generally, his proposition was that the linkage between caste and occupations in modern industrial has never been proven.

It is interesting that this distinctive institution of caste has been almost entirely ignored in connection with Indian industrialization. No detailed study of the relation of caste to industrial work is available. In the vast array of official investigations into the conditions of industrial labor, virtually the sole reference to caste relates to caste dietary restrictions, which employers claimed prevented them from establishing factory canteens. The institution has been treated mainly by anthropologists, and almost entirely in its rural setting. Those who have studied caste have ignored industry, and those who have studied industry have ignored caste. ${ }^{\text {IOo }}$

Little of this disregard is noticeable in later research. Indeed, in a wide variety of empirically-based reports the relationship between caste and factory employment is brought forward as a significant factor. ${ }^{\text {Ior }}$ These studies are fairly systematic in pointing out that the workforce approximately reflects the caste composition of the urban population as a whole. That correspondence also applies to the high-low distribution, in the sense that middle and higher castes are over-represented in the higher echelons of industrial work hierarchy, ${ }^{\mathrm{IO} 2}$ while the bottom ranks are mainly occupied by members of lower castes. It should be noted that this correlation is by no means a linear one, but is affected strongly by differences in educational levels. But has the growing discrepancy between the limited supply of industrial work and the enormously increased demand led to exclusion of the socially-deprived categories? That assumption is certainly not groundless. Harriss, amongst others, reported on such discriminatory practices. ${ }^{\mathrm{IO}} \mathrm{On}$ the other hand, however, the policy of positive discrimination adopted with regard to public sector employment has prioritized the employment of candidates belonging to scheduled castes/tribes. To some degree this has enabled a growing number of low-caste candidates to penetrate to higherranking jobs in the industrial hierarchy which were formerly inaccessible to them. At the same time, in capital-intensive, i.e. technologically advanced industries, particularly corporate and multinational concerns, staff are recruited almost entirely on the basis of requirements that show a strong bias towards the higher social classes. Nevertheless, confirmation that the

99. Morris, Emergence of an Industrial Labor Force in India, pp. 200-20I.

I00. Morris, "Labor Market in India", pp. I82-183.

IOI. E.g., Sheth, Social Framework of an Indian Factory, pp. 73-75; Holmström, South Indian

Factory Workers, pp. 32-34; Ramaswamy, Work, Union and Community, pp. Io2-II4.

I02. Sharma, "Industrial Workers", p. I3.

I03. Harriss, "Character of an Urban Economy", p. 999. 
structuring principle of India's society is still recognizable inside the factory gates does not mean that caste retains the ideological significance that it was ascribed in the past.

[...] caste is no longer plausible as a thorough-going religious ideology, justifying all social and economic relations as parts of a divinely established hierarchy. The main public ideology - not just the language of politics and unions, but much ordinary talk - tends to stress moral and social equality. The status inequalities that count depend on jobs, income, life style, manners and education. Where these things go with caste rank, this is usually because some castes had more access to education and good jobs in the past - a situation that will not last, because effective caste job-finding networks are not stable or confined to high castes. ${ }^{\mathrm{IO4}}$

Our conclusion might well be the same as that which Sharma reported, almost twenty-five years ago, as the main finding of his industrial research, namely, that factories gave preference to "the educated workers over the non-educated, urban-born over the rural-born, and those with industrial experience over the ones having no experience or with a background in non-industrial occupations" ${ }^{\text {Ios }}$

This does not complete the social profile, however. What is lacking, in the minimal sense, is the gender dimension. Early studies of industrial employment give the impression that women were rarely to be found in factories. Their suggested absence motivated Kalpana Ram to argue that "the virtual exclusion of women from the Indian industrial working class has drawn little theoretical comment" ${ }^{\text {I06 }}$ She gave this judgement after considering the far higher participation of women in the early industrialization period in Western countries as well as in various low-income societies more currently. Her opinion needs some qualification in view of the fact that in Mumbai's cotton mills at the end of the nineteenth and in the early twentieth century, for example, women made up one-fifth to one-quarter of the workforce. ${ }^{107}$ Although that was far less than in Western societies at the emergence of the textile industry, it was certainly not negligible.

How are we then to explain the fact that steady growth of the industrial sector brought a fall rather than rise in the percentage of female factory workers? The primary cause reported was the introduction of factory legislation which restricted the use of the far cheaper labour of women and children in the first few decades of the twentieth century. Morris finds this explanation rather spurious. More important in his opinion is that women's reproductive role causes them to absent themselves more frequently, thus giving them the reputation of being a nuisance. However, that argument is

I04. Holmström, South Indian Factory Workers, p. 80.

I05. Sharma, Indian Industrial Worker, p. I4.

I06. Ram, "Indian Working Class and the Peasantry", p. I82.

107. Morris, Emergence of an Industrial Labor Force in India, p. 65. 
not compatible with huge local variations apparent in the employment of women in the textile industry throughout the country. Morris considers the marginalization of the female sex to substantiate his thesis that there was no lack of male workers who, in the last instance, were preferred by the industry. ${ }^{108}$

In the mid-twentieth century industrial work was perhaps more than ever before a male preserve. By then the public image of a factory worker had become that of a young man no more than thirty to thirty-five years old. Official reports such as that by the National Commission on Labour confirm the decreasing participation of women in the industrial work process.

This decline has been more marked in the textile and basic metal industries. In both cotton and jute textiles, the decline of women's employment is attributed mainly to technological changes rendering the jobs held by several women workers redundant. Fixation of minimum workload and standardization of wages in the cotton textile industry necessitated retrenchment of women workers who were working mostly as reelers and winders where the workload was found to be lower [...] Rationalization and mechanization schemes in the jute industry eliminated some of the manual processes which at one time were the preserve of women workers. Certain occupations giving employment to women in the jute industry earlier were found to be hazardous and are therefore closed to women now by Rules framed under the Factories Act. ${ }^{\text {I09 }}$

Similarly to many other publications, the Report NCL states that women's eclipse from the factories was caused partly by the rationalization of production and partly by the weaker sex being relieved of labour which, on second thoughts, was considered too strenuous. In the first case, their removal was attributed to the fact, apparently thought irrefutable, that women's performance lagged behind not only that of machines but also that of men. In the second case, women's exclusion was presented as the deplorable result of a well-intentioned measure, namely, protection of their welfare. Where the emphasis should be placed, however, is on the fact that the progressive mechanization of industrial work has further strengthened the male dominance that became a more common feature of economic life.

In factories where machines are not only used but also made, women seem to disappear from view entirely. While Sharma at least reported that only males were employed in the car manufacturing plant researched by him, ${ }^{\text {IIO }}$ Sheth totally omits to point out why, in the factory of his research, the workforce apparently did not include even one woman. Also, in factories where both sexes are employed, women are invariably far in the minority. Lambert reports that in 1956 in India as a whole women formed only II.7 per cent of the workforce in manufacturing industries, concentrated mostly

I08. Ibid., p. 69.

I09. Government of India, Report of the National Commission on Labour, p. 380.

Iı. Sharma, Indian Industrial Worker, p. 7. 
in medium-sized to large enterprises. ${ }^{\text {III }}$ Women were present in only two of the five factories in Pune that were the target of his research. The sample on which Lambert based his analyses consisted of 96.6 per cent of males. Although this underrepresented the average share of women in the enterprises in question, Lambert did not correct the imbalance in his data set. This also applies to Holmström's study in Bangalore of the workforce in four industrial enterprises. In the case study sample to which he narrowed-down his research, women's share amounted to only 5.6 per cent, far lower than their fifteen per cent of the factory population in Karnataka State as a whole. ${ }^{\mathrm{II}}$ The underexposure of women workers in the industrial production landscape is thus not unconnected to a code of social conduct which makes them less easy to approach not only by male researchers but also by male co-workers.

[...] the one woman "draftsman" says the men in her office treat her as a sister, but she never goes among the men on the factory floor to discuss design problems, and so she cannot get promotion. Women keep to themselves in the canteen, play a minor part in most clubs and then only in the shadow of their husbands, and take little part in the union beyond attending general meetings and voting. ${ }^{\mathrm{II}}$

It cannot be coincidental that, in her fieldwork in an industrial neighbourhood in Coimbatore, Uma Ramaswamy did not overlook the position and problems of female workers. The information that they formed fifteen per cent of the total workforce was accompanied by the observation that their participation, in absolute as well as relative terms, was declining. ${ }^{\text {IIt }}$ In this case the cause of women's marginalization is again part of a trend towards mechanization by which they in particular become victimized. At the time of Ramaswamy's research, the output of one woman equalled that of five a few decades earlier. Women's employment is falling even though their productivity is higher than that of male workers. Why is it, then, that the sexual balance is becoming even further distorted? It boils down to the fact that in practice it is easier to let men take the place of women than vice versa. In addition to all manner of inhibitions connected to the employment of women, and regardless of their willingness to work night shifts for example, there is the fact that they have to be paid while on maternity leave. Such protective measures have helped to reduce the differential wage level. This means that the customary reason for employing women, i.e. their attraction as cheap labour, has lost some of its value. Women who are superfluous to needs are dismissed or transferred to departments where they are given unskilled work and thus suffer reduced earnings. Investigations have repeatedly shown that women are invariably the lowest paid workers.

III. Lambert, Workers, Factories and Social Change in India, p. 23.

II2. Holmström, South Indian Factory Workers, p. I9.

II3. Ibid., p. 65.

II4. Ramaswamy, Work, Union and Community, p. 22; see also Fernandes, Producing Workers. 
Insofar as they have not been completely ousted from the industrial labour process, women seem principally or exclusively to be assigned tasks by management which need no special knowledge or skill and may be quite monotonous, but nevertheless require precision and alertness.

When a certain job requires, in the employer's eyes, delicate handling, or when the work is time-consuming and tedious, women are called upon to do it. Thus, women are favoured in the electronics industry, for jobs which require tiny parts to be handled gently and carefully, and where fine wires have to be twisted and wound. In the textile industry, women have traditionally been employed as menders, spinners, winders, reelers, folders and cottonwaste pickers. In the pharmaceutical industry, women are generally employed as packers. ${ }^{\text {II5 }}$

These are all activities which leave women, far more than men, riveted to the bottom of the work hierarchy with no prospect of promotion.

\section{LIFESTYLE}

Factory workers are recruited from very different social milieus. Nevertheless, they share with one another a number of characteristics that have to do with the industrial culture in which they work and live, and which distinguish them from other components of urban and rural labour. The expectation that a more homogeneous lifestyle would eventually emerge caused diverse researchers to investigate the effect of the industrial-urban setting on the household as unit of identification. Much of the literature portrays the industrial worker as a man frequently living apart from his family and leading a bachelor's existence in the city. ${ }^{116}$ In due course, when the male worker had become thoroughly rooted in the industrial sphere, he was joined by his wife and children who had been left behind in the village. It is interesting to note that in southern India labour migration was coupled far less with the break-up of the family. When a man settled in the city he was either accompanied by his family members or did his best to enable them to join him at the earliest possible time. ${ }^{\mathrm{II} 7}$ In Kerr's jargon, family reunion at the place of employment marked the transition from the type of "uncommitted" to the "committed" worker.

He is fully urbanized and never expects to leave industrial life. His family is permanently resident in an urban area, and it is not unusual for the wife also to enter the labor market. In fact, one good test of the degree of commitment of a labor force is the percentage of it comprised by women. An uncommitted or semicommitted labor force is predominantly male. The committed worker depends for his security on his employer and on the state, not his tribe. His way of life is industrial. ${ }^{\mathrm{I} 8}$

II5. Quoted in Holmström, Industry and Inequality, p. 227.

II6. Das, "Indian Working Class", p. I65.

I17. Holmström, Industry and Inequality, p. 68.

II8. Kerr, "Changing Social Structures", p. 353. 
The untenability of the commitment concept is shown clearly by the unfeasibility of using women's participation in the industrial labour process as its yardstick. As we have seen, the problem is not that women lack the willingness and ability to enter the factory, but rather that they are not given the opportunity. Those who do manage to penetrate into the ranks of factorized workers do so thanks to the same support mechanisms used by the men when seeking such regular employment, i.e. mediation and recommendation by superiors, neighbours, friends, relatives or any others who happen to have the right "contacts". This explains why it is that women who work in a factory are frequently the wife, sister, daughter or other relation of a male worker in the same enterprise. As pointed out by Ramaswamy, the greatest favour that a worker can hope to gain from management of enterprise or trade union is a job for his wife. If both are able to work the result is an income that many a middle-class household would regard with jealousy. ${ }^{\text {II }}$

In the early social science literature of factory labour in India, the transition from caste to class - not whether but when this would happen - was the subject of much discussion. This also applied to the question of the break-up of the joint family, given its incompatibility with the industrialurban lifestyle. ${ }^{\mathrm{I2O}}$ Both institutions were considered to represent the traditional culture and structure for which there would be no place as the transformation progressed towards an economy that was no longer dominated by agriculture and the countryside. Did not the much smaller size of the average household in industrial locations signal the advance of the nuclear family? Nevertheless, doubt gradually arose regarding this notion of parallel development along Western lines. Moreover, there was the growing realization that for a very large segment of the rural population in the past the joint family had not been the only or even most common unit of cohabitation. And did not the concept of jointness radiate an extraordinarily biased sense of patriarchy which gave a distorted view of women's position in the familial structure? In an early essay on this theme, Singer reported on his research into the preservation, albeit in a streamlined form, of the joint family among the industrial elite of Madras. ${ }^{121}$ A number of authors, in accord with the idea that the modernization process caused a certain degree of ambiguity between the public and private spheres, opined that industrial workers at home and among their family kept to the caste code, which entailed far more than seeking a marriage partner in their own circle.

II9. Ramaswamy, Work, Union and Community, p.25; see also Holmström, Industry and Inequality, pp. $227-228$.

I20. See, among others, Goode, "Industrialization and Family Change".

I2I. Singer, "Indian Joint Family in Modern Industry". 
On the other hand, their social behaviour at work was determined by the consciousness that, together with their fellows, they belonged to the working class. Singer's use of the term "compartmentalization" refers to this division: "the home becomes the sphere of religion and traditional values; office and factory become the sphere of business and modern values". ${ }^{222}$ His conclusion regarding the coming into being of a modified joint family organization is not very convincing, not least because it is founded solely on the state of affairs in the households of Chennai's captains of industry. The lifestyle described by Singer is anything but representative of that of factory workers. Nevertheless, Lambert seems to use more or less the same argument with regard to this part of the workforce. On the basis of quantified data, he observed that the social unit in which the employees of five industries in Pune lived was not noticeably different from that of the city's population as a whole. Moreover, the households of industrial workers included on average more members and this, according to Lambert, contradicted their proclaimed transition to the conjugal family. Apart from the parents and their own children, the households of factory workers frequently included all kinds of resident but non-working relatives. ${ }^{123}$ It is by no means certain, however, that such a household composition means that the authentic joint family is preserved. Without contending that the nuclear family is a new institution in Indian society which originated in the urban-industrial setting, I agree with Holmström that, for the average factory worker:

[...] the earning and spending unit is the nuclear family settled in the city, depending on one main earner, which expands to take relatives in need and then goes back to its normal size; linked to relatives elsewhere by bonds of duty and sentiment which are sometimes expensive. ${ }^{\text {I24 }}$

Such alternation of growth and shrinkage is based on obligations towards one's own relations or in-laws, who are almost always caste fellows. At the same time, the cramped living space limits the possibility of housing these close relatives indefinitely. I hesitate to speak of "normal size", however, because in my opinion this is too suggestive of an underlying pattern as an ideal to which concessions must be made in day-to-day life. An industrial way of life makes its own demands on the household. The inclusion of more members for a shorter or longer period arises partly from the necessity to broaden the unit's economic base by increasing the number of workers. To draw a cultural contrast between the tradition of a joint family and the modernity of a nuclear or conjugal family is to ignore the fact that the predominant working-class household in the industrial-urban milieu belongs to neither. Rather, it is a unit of cohabitation forced into

I22. Ibid., p. 438 .

123. Lambert, Workers, Factories and Social Change in India, p. 56.

I24. Holmström, Industry and Inequality, p. 274. 
being by the low earnings of labour power and specific conditions of employment. ${ }^{\mathrm{I2S}}$

The authors of the Report of the National Commission on Labour, which paid principal attention to the material features of working life, observed that the quality of accommodation for industrial labour had improved in comparison with the first generation of ahatas in Kanpur, the labour camps in Bombay, the shanties in the south and the bastis in eastern India which, since being built long ago, had only become even more miserable and congested. True, new urban housing has been constructed in special settlements, but even these colonies are almost immediately burdened by overcrowding. Large industrial enterprises sometimes have their own housing estates that are of quite respectable quality, but this is a comfort granted to only very few. The greater proportion of the working masses have to make do with primitive and confined living quarters in neighbourhoods that are mostly dilapidated and sordid.

But even in this dismal surrounding, the worker endeavours to keep himself clean. Real change is seen inside the tenement. Earthen pots have been replaced by aluminium or brass-ware; pieces of crockery are not an unusual possession. There are also items of furniture, such as charpoi, a bench or a chair and a mosquito net. Radio/transistors/watches are often the proud possessions of not a few. ${ }^{\text {I26 }}$

This list of durable consumer goods, by now already almost thirty years old, could be increased with a number of more recent gains: a sewing machine, a bicycle or even a Hero Honda, modern cooking implements, a fan, a refrigerator and television. Furthermore, and not to be forgotten, tap water and a shared or even individual toilet, although almost without exception an outdoor one. The Report NCL similarly describes the expansion of the new consumption pattern in terms of food and clothing. Meals that were previously linked to a certain region, e.g. based on wheat in the north and on rice in the south, are now common good throughout the nation. Factory canteens played an important role in this expansion. Some food items are now not only prepared at home but are also bought ready-made. Clothing and footwear has increased both in quantity and quality; to some degree it is standardized for adults and children throughout the country, and is also frequently bought ready-made. Many labourers now wear overalls in the factory; they are no longer unshod and garbed only in short baggy trousers and a vest as in earlier days.

Is it possible, with the aid of these details, to compile a portrait of the average factory worker? That is difficult because, for a start, the differen-

125. "Report of a Survey: Working-Class Women and Working-Class Families in Bombay", p. 1169 .

I26. Government of India, Report of the National Commission on Labour, p. 33. 
tiation among them is so strikingly apparent. The upper bracket consists of employees of capital-intensive multinational corporations who should be included in the expanding middle class, not only because of the nature of their employment but also due to their lifestyle. At the bottom is a colossal army of unskilled and semiskilled workers in industries that lack almost all advanced technology and have far less attractive working conditions. These workers are not really badly paid but nevertheless have all reason to feel threatened by the continual demand that they increase their low productivity; they have more difficulty in ensuring their daily survival and in passing their jobs on to the next generation.

However great the distance may be between these two poles, factory workers do have a number of characteristics in common. These include in the first place the fact that they are in regular employment. Closely connected to this is the fact that the greater majority receive on the weekly or monthly pay day a wage that fluctuates little; in short, the wage is calculated according to the number of hours worked. This also implies a clear distinction between working and non-working times. "Eight hours of work and you are free", as one informant explained to Holmström. ${ }^{127}$ This naturally does not entail that they never work overtime or that they can avoid shift work. Finally, their conditions of employment - not only appointment, promotion and dismissal, but also a great diversity of secondary provisions regarding illness, vacation, pension, dearness allowance, bonus, etc. - are tied to well-defined rules. Those regulations are laid down in legislation which was partly brought about by pressure from trade unions established to take care of the workers' interests. It is due to this combination of characteristics, i.e. regular work and wages together with a livelihood that is reasonably secure and protected, that I consider the workers in mediumsized and large industries as the dominant class in the industrial sector of the modern economy. Their lifestyle has been summarized by Holmström as follows:

These factory workers have much in common. They belong to a distinctive Indian industrial culture, with typical assumptions and expectations and tastes which cut across divisions of skill and age and origin. They share a common situation. They act, and sometimes think of themselves, as a group (if not a class) different from peasants, workers in the "unorganized" sector or in older factories with different technologies, from casual labourers, shopkeepers, professional people and so on. ${ }^{\text {I28 }}$

Such workers represent only a small minority. If I nevertheless call them dominant it is in the sense that they have a high profile as a social category, that they are respected and act as trend setters, conscious of the example that they set for others. But do they also form a privileged segment, an elite who, similar to members of the dominant caste in the agrarian-rural sphere,

I27. Holmström, Industry and Inequality, p. 2I.

128. Holmström, South Indian Factory Workers, p. 27. 
have appropriated a disproportionate portion of scarce goods and thus have helped to exclude other far larger formations? Opinions differ on this.

Comparatively speaking, factory workers in regular employment are not badly paid. The basic wage, which increases with the number of years worked, is supplemented by a prices allowance and other benefits. The level of total earnings is noticeably higher than that of comparable sections of the proletariat who have no formal labour contract with their employers. In addition to their better primary conditions of employment, factory workers are distinguished by recognition of their claim to social provisions that insure them against risks and from which their family members also benefit. These workers well realize that they are not only better paid for their efforts, but that they are better able to cope with adversities at home or at work thanks to the security network that gives a more solid basis to their existence. They are not prepared to share these material gains with the far larger mass of workers in the industrial economy who have so far been deprived of them. Any such show of solidarity with the vulnerable category of temporary workers, even in the same enterprise, seems to be arrested by the not unrealistic fear that any extension of better and protected working conditions to this pool of casual labour would detract from the self-interest of the fairly modest contingent of those who now enjoy them. Exclusion and inclusion are mechanisms that are very closely connected. The fact that it is impossible to demolish the high walls thrown up around the enclaves of comfortable and guaranteed employment is due partly to the apprehension of those who have barricaded themselves behind them that they will lose their own advantages. Would not lowering the wall or building more entrance gates bring the danger of inundation? There has never been any lack of warnings that the industrial vanguard, rather than making any effort to secure better conditions for the much larger army of those who lag behind, has developed into a class that is solely interested in further strengthening its own privileged position. Seen from this point of view:

$[\ldots]$ it is the organizational strength of industrial labour that prevents the transfer of resources from urban to rural sector and thereby to agricultural labour. If the power of the industrial labour is curbed and it is prevented from exploiting its strategic location in the growth of the Indian economy, efforts can be made to improve the lot of the rural poor. ${ }^{129}$

The author summarizes this as conventional wisdom but holds a different opinion himself. Pointing out that, over the years, the rise in industrial wage levels has only been in reaction to strong increases in the costs of living, he rejects the suggestion that capital accumulation has been delayed by profits being drained off towards labour for consumptive purposes. Other authors have less difficulty in insisting that workers in industry's organized 
sector form an aristocracy among the working masses. Their advanced position explains why the gap between their income and the wages paid to agricultural workers all over India, for example, is now far greater than it ever was in the past.

\section{THE ASSERTION OF DIGNITY}

An important feature marking factory workers in regular employment as a special category is that they have amalgamated into trade unions to negotiate further improvement in their conditions of work and to defend the rights that they have gained with so much difficulty. The state has also played an important role in this respect. Labour legislation that was introduced after Independence consists largely of regulations intended for a fairly small upper bracket of the working population. The fact that government concern was primarily if not exclusively directed towards what have been called assault troops in the process of industrialization was not caused by any feelings of benevolence. It was, on the one hand, a concession to the power that had been built up by the factorized proletariat during preceding decades and, on the other hand, the inevitable consequence of the commanding role of the state in the transition from an agrarian-rural to an industrial-urban type of society. The more general idea was that protection of industrial capital by a system of licences and controls should also be extended to labour by ensuring fair wages and an adequate life standard for industrial workers.

Discussions in the National Planning Committee in 1940 on the labour problem were based on a report drawn up by a sub-group. At stake was the installation of an industrial machinery such as already existed in Europe in particular. This was coupled with the introduction of extensive legislation regarding conditions of employment and their compliance. These included delimitation of the working week; prohibiting the use of child labour; provisions for sanitation, health and safety at work; the fixing of a minimum wage and how this should be put into practice; equal pay for equal work by men and women; the right to a paid vacation; maternity benefits; housing quarters; procedures for settling conflicts; and compulsory arbitration by government which necessitated the setting-up of a Conciliation Board and an Industrial Court. Following all this, the creation of a system of social security was also discussed.

A system of compulsory and contributory social insurance for industrial workers should be established directly under the control of the State to cover the risks of sickness and invalidity other than those covered by the Workmen's Compensation Act. Schemes for providing alternative employment to those involuntarily employed. Old Age Pensions and Survivors' Pensions, and also Social Insurance to cover risks of sickness and invalidity for all, should be established directly under the State. These schemes should be extended by stages, priority being given to 
particular classes of workers, with due regard to the relative urgency of their needs facility of application, and to the ability of the community to provide for them. ${ }^{\mathrm{I} 30}$

The latter sentence was intended to act as a brake to any exaggerated expectations. During the deliberations, however, Ambalal Sarabhai, President of the Ahmedabad Mill-Owners' Association, who acted in this tribunal as representative of the employers, raised the question of whether the entire package of new measures and regulations was really intended to be introduced in the short term. The Chairman, Jawaharlal Nehru, explained that it represented a co-ordinated scheme of action which did not allow for any piecemeal selection. He showed rather more flexibility with regard to the date of introduction. The scenario that had been drawn up was intended to provide direction to the future development of the nation and it was self-evident, he reassured Sarabhai, that the plans could only be put into implementation after the transfer of power.

The need to pacify labour was due to the realization by the nationalist leadership that the mobilization of industrial workers which had started in the colonial era and had expressed itself in strikes and other forms of protest, might perhaps gain new impetus rather than fade away after the liberation from alien rule. Registered trade unions in India totalled twenty-nine in 1928 and 3,987 in $195 \mathrm{I}^{\mathrm{I}}{ }^{31}$ Such explosive growth implied that economic policy must inevitably make allowance for this institutionalized interest. Although the trade unions cared for the interests of only a tiny minority of industrial labour, that minority formed the most vocal and most militant portion of the working masses. Hope was expressed that, in exchange for special treatment, this vanguard of "the dangerous classes" would abandon any more extreme demands and would devote their efforts, in a constructive and loyal manner, towards building the nation's economy. Peasants and workers were told ad nauseam that they had to sacrifice their own interests for the good of the whole nation. During discussions of the labour problem, entirely in accord with that philosophy, one member of the National Planning Committee suggested that there should be no room for industrial unrest in the planned economy. Nevertheless, the fear of radicalization of the factory proletariat, whose numbers were bound to increase rapidly, was great. The workers' efforts, through strikes and other militant forms of agitation, to improve their working conditions has been dismissed by some of the literature as irresponsible and irrational. Kanappan, for example, entirely in agreement with the current emphasis on discipline as being a major problem, stated that the workers' rebellious attitude evidenced an anomic reaction to the industrial environment. In his opinion the government had every reason for concern. "As late as in the sixties, Indian authorit-

I30. Minutes National Planning Committee, May 1940.

I3I. Ornati, Jobs and Workers in India, p. xi. 
ies were concerned with violence or unruly and abusive behaviour in the coal mines. In the modern Rourkela steel plant, in an automobile plant in Bombay, and other places too numerous to mention here. ${ }^{{ }^{132}}$ In the effort to combat the threatening danger of a shift in the balance of social power relations, the politicians used a number of strategies. Firstly, they successfully encouraged the rise of trade unions that were linked to various political currents. Their mutual rivalry prevented the labour movement as a whole from forming a united front. Second, all efforts were made to avoid or defuse any direct confrontation between employers and employees. The priority given to harmony and reconciliation in industrial relations and the prescribing of arbitration meant that the state itself became a principal party in negotiations over wage demands or other disputed matters. This tripartite consultation became a significant principle in labour policy. The final piece of strategy was the attempt, with the aid of extra benefits and facilities, to detach the industrial elite among the working population from its links with the far greater mass of workers. This enormous army of underprivileged labour was excluded from formal wage negotiations, and there was no institutionalized and organized promotion of their interests.

A Fair Wages Committee was given the task of finding out how much an industrial worker needed to provide for himself and his immediate family.

[...] it should enable the male earner to provide for himself and his family [N.B.: identified as a unit of man, wife and two children] not merely the bare essentials of food, clothing and shelter, but a measure of frugal comfort, including education for the children, protection against ill health, requirements of essential social needs and a measure of insurance against the more inevitable misfortunes including old age. $^{\text {I33 }}$

It is interesting to note that this exercise was undertaken in the third quarter of the twentieth century, at the end of a period when women were expelled from the factories with the message that they should devote themselves to their reproductive tasks. Payment of a living wage, as described above, remained a far distant ideal. Employers' unions argued that even the "measure of frugal comfort" signified a burden that was too heavy. For the time being they were only prepared to grant a fair wage if the other party would agree to increase production and to maintain industrial peace. This was not an unattractive proposition in that even the fair wage fixation was far above the income level with which the greater part of the working population had to survive. Until the beginning of the I96os, the illusion was maintained that industrialization was instrumental in the transition towards a socialist society. In addition to the granting of a fair wage and bonus policy together with the acceptance of collective bargaining, industrial socialism ultimately

132. Kanappan, "Labor Force Commitment", p. 315; see also Myers, and Kanappan, Industrial Relations in India, p. II3.

133. P. S. Loknathan, in Papola et al., Labour, Employment and Industrial Relations in India, p. 5I. 
also signified the introduction of workers' participation in management, developing into profit sharing. ${ }^{\mathrm{I} 4}$ It is hardly necessary to record that this has never been achieved.

The class-consciousness of the factory workers is demonstrated by their proven willingness to organize themselves. Membership of a trade union is seen as evidence that they are prepared to take collective action and as a clear expression of their feelings of solidarity. But is that interpretation plausible and justified? Doubt in that respect arises firstly from the realization that by no means all workers in what is called the formal sector of the economy became members of a trade union. Even when we accept the strongly inflated figures provided by the major organizations about the size of their following, less than one out of three workers in this high-profile segment of the industrial labour force were registered members. If regular payment of the union fee is the criterion the magnitude shrinks much further. When all's said and done, the hard core of trade unionists consists of a rather small minority. Although identified as the vanguard of the working class, they show no inclination to join the struggle for improving the plight of the non-organized masses. They are said to be interested primarily in maintaining their own privileges and to dissociate themselves from any claims for support and solidarity made from below. Seen from this viewpoint, such protected workers are more interested in maintaining the closed-shop nature of their regular factory jobs than in taking action to improve conditions for others by extending their solidarity outwards and thus also downwards.

Confirmation or negation of the thesis regarding egoism on the part of the labour aristocracy in safeguarding their own interests needs to be tested on the basis of empirical research that focuses on relations between industrial workers and the trade union. The best study remains undoubtedly the one published by E. A. Ramaswamy already more than two decades ago. On the basis of fieldwork in Coimbatore, this author has charted local interactions between a selected trade union and its members employed in cotton mills. The picture arising from his study confirms that the millworkers keep a sharp eye on whether the union's cadre exert themselves in caring for the complaints and wishes of the members, whether individual or collective. On the other hand, the workers show acute awareness that their existence is far more comfortable than that of the great masses who have no-one to defend their interests. In the words of a senior union member: "There is a limit to what we can ask from the mill-owner. I get four times as much as my neighbour who toils in a field all day, and yet my job is easier and not very much more skilled than his. Unless conditions

134. Joseph, "Workers' Participation in Industry", pp. I23-I39; R. K. Mukherjee, in Papola et al., Labour, Employment and Industrial Relations in India, p. I09. 
improve all around it is difficult to get us to ask for more." ${ }^{135}$ Contrary to what seems to be suggested by the title of Ramaswamy's book (The Worker and His Union), trade union members also include women. They are said to be fairly passive and to do no more than pay their contributions. Ramaswamy observes that women have little time in which to hang around. After finishing their shifts, they have to hasten away in order to care for their households. If their jobs are endangered, however, or problems arise of another nature, they show themselves to be extremely militant. At the time of the research they had every reason to assert themselves because women in particular threatened to be victimized by staff cuts. We have seen earlier that women are found in the lowest ranks of the labour hierarchy and often get no further than casual work. Whatever their sex, such workers who are kept in the pool of reserve labour have greater need than regular workers for a union's help and protection. This claim is not only opposed by the employers. ${ }^{136}$ Trade union leaders, whether or not pressurized by their members, show little zest for accepting such outsiders and even a distinctly negative reaction if efforts are undertaken in that direction. Can the unions be blamed for such negativism? Holmström is not convinced and points out that they have their hands full with maintaining whatever they have achieved. Consolidation of their gains is difficult enough, let alone that they should have to defend the interests of a mass of workers who are far more vulnerable. Even more than for the badlis, who at least have been able to join the pool of reserve labour to await their turn for a job, that vulnerability affects the infinitely greater mass who have not yet found their way into the waiting room but, on the contrary, are kept far away from it.

Many unions are overwhelmingly defensive. They are there to protect jobs first, then the real value of wages against inflation, with safety and working conditions a poor third, rather than to win more than the members have already. They know their bargaining power is weak; noisy militant demands for more are a tactic to hold the line, something to be bargained away when vital interests are threatened. The union has a hard enough job protecting its own members without worrying about outsiders. ${ }^{\mathrm{I3}}$

Other authors are far more critical of the activities of trade unions. ${ }^{138}$ Their leaders in particular are said to be manipulative and corrupt, more interested in their own advantage than in caring for the interests of the rank-and-file. Workers react to such behaviour by making their faith in the leaders dependent on the results they achieve. If these are disappointing they have no hesitation in defecting to a rival union. The choice is not a question of ideology but the more pragmatic one of who offers the most for the lowest

135. Ramaswamy, Worker and His Union, pp. 182-I83.

136. Ramaswamy, Work, Union and Community, p. 2I.

137. Holmström, Industry and Inequality, p. 289; see also Das, "Indian Working Class", p. I74.

138. E.g. Mamkoottam, Trade Unionism: Myth and Reality. 
price. According to such authors, trade union bosses operate as brokers, similar to the earlier labour jobbers, and use their mandate to enter into deals with employers, politicians and rival unions. This is a critical view which makes it understandable why the factorized workforce is organized only to a fairly low degree. To keep one's distance from a trade union, however, could also be seen as demonstrating loyalty to management or, to put it more bluntly, as fear of becoming known as a potential troublemaker. The setting up of unions in which workers were brought together, and the battle which had to be fought in order to break through employers' fierce and tenacious resistance to collective action, is perhaps the principal reason why the present generation of factory workers continues to trust in organizations that were set up to defend their interests. A contributory factor is that, in the residential areas more than in the workplace itself, the memory still lives on of champions in the fight for a better life who often had to pay a high price for their ideals and dedication. These were not the great names in trade union history but rather local-level leaders, some of whom came from the ranks. Sheth, who concluded that the union had only marginal significance for the workforce in the factory researched by him, nevertheless qualified that conclusion as follows:

[...] workers realized that though the union achieved precious little for them, they could achieve even less in the absence of a union. Individual workers could make a comparison in retrospect between "union days" and "unionless days" and found that though the union got them hardly anywhere in relation to the demands it made on the management, it was necessary for systematic dealing with the management. ${ }^{\mathrm{I} 9}$

I tend to regard this as adequately representing an opinion commonly held in the milieu of protected and organized labour. It is difficult to see it as the easy-going and also short-sighted aristocratic mentality of après nous le déluge. The attitude taken by the industrial vanguard seems rather to be caused by the fear that the cake, i.e. the comfort of a relatively secure existence, is too small to be divided amongst all comers.

It is also my view that the trade union movement did in fact play an emancipatory role in India. Perlin is quite correct in pointing out that little if any improvement has been brought about in the deplorable forms of factory labour. In a great many enterprises, working conditions are injurious not only to health but also to human dignity. ${ }^{\text {I0 }}$ The light-hearted opinion held by compilers of the Report NCL to the effect that industrial workers had become accustomed to such hardships and more or less ignored them, ${ }^{141}$

139. Sheth, Social Framework of an Indian Factory, pp. I59-160; see also Sharma, "Union Involvement Revisited”, p. I239.

I40. Perlin, "Ragi, Roti and Four-Yard Dhoties", p. 457.

I4I. Government of India, Report of the National Commission on Labour, p. 35. 
does not appreciate that the workforce suffers from the extremely unhealthy conditions that characterize the production process and unmistakeably feel polluted by them.

All this does not alter the fact, however, that factory workers in regular employment have made great progress, particularly in their own self-esteem. That has been due not least to the protection offered by membership of a trade union. Conversely, that self-esteem encourages them to organize themselves, even when this is likely to arouse displeasure among their bosses. A principal conclusion reached by the National Commission on Labour was that "the industrial worker of today has acquired a dignity not known to his predecessor". Employers in talking to the NCL used a somewhat different jargon which showed irritation regarding "[...] a greater measure of defiance towards his superiors". Also according to the same source, the greater degree of assertiveness was based on greater awareness: "a worker today is more politically conscious than before, more articulate of the existing order and more sensitive to his conditions and hardships". ${ }^{142}$ There can be little doubt that the dignity gained was both cause and consequence of the social struggle spearheaded by the labour movement on a broad front. Its cadre members became the role models whose charismatic behaviour induced the less active and less conscientized factory workers to assert themselves, even if only temporarily. The research carried out in Coimbatore by both E. A. and U. Ramaswamy illustrates this in lively and forceful fashion.

The Ramaswamys describe in detail - with sketches of individuals and their life histories and thoughts - a world of the union activists [...] held together by an ideology of working-class solidarity cutting across barriers of caste and employment. By their personal example, they carry along the mass of ordinary workers who are moderately apathetic about wider issues, but still loyal enough to strike, demonstrate and perhaps vote when asked by those they respect. The union provides a service when needed; in return it sometimes asks for sacrifice and enthusiasm. $^{\text {I43 }}$

Wage increase is undoubtedly the most urgent demand made by the trade union movement since its inception. However, its programme of action immediately became much broader and far outdistanced this primary target. Through the very nature of their existence, the organizations in which factory workers were united protested against the strict hierarchical order, not only in industry but in society as a whole. That hierarchy instructed that labour must resign itself to its own subordination. The ideology of the trade unions, however great their mutual diversity, could do nothing other than nurture the principles of equality and social justice. Corruption of those ideals was linked to everyday party-political practices and also resulted from contradictory opinions that prevailed among the working masses. After all,

I42. Ibid.

I43. Holmström, Industry and Inequality, pp. 294-295. 
a great proportion of the workers originated in a milieu that was by no means averse to distinctions according to caste and class, to ethnicity, faith or colour. It is thus all the more significant that "the main public ideology not just the language of politics and unions, but much ordinary talk - tends to stress moral and social equality".${ }^{\text {I44 }}$ Asserting one's dignity essentially also meant the denial of dependency and inequality. This met with considerable oppression, however, since employers attach great significance to recognition of their traditional authority. They quite rightly see industrial agitation as undermining their claim to respectful obedience. This feudal-like attitude is illustrated by the following appeal with which, at the start of the I950s, one employer called his striking workers to order.

Your illegal and indisciplinary ways distress me. I am tired and will be compelled to take action [...]. My advice to you as your elder and wellwisher is work wholeheartedly and maintain discipline [...] if you do not follow my humble advice you will compel the company to dismiss all those who act illegally as we have waited patiently for long [...]. ${ }^{\mathrm{I} 5}$

The arrogance shown by the employer together with the assumed timidity of his inferiors give a time-bound flavour to this exhortation to good behaviour. Three decades later such a statement would have been greeted with utter hilarity.

During the 1970s and 1980s drastic changes took place in the system of labour relations caused by a thorough restructuring of the industrial economy. Rationalization of production became a major trend, first in private business but subsequently also in public sector enterprises, which resulted in the downsizing of employment. Between 1968 and 1984 the average number of production process workers per factory declined from seventyfive to sixty-one. ${ }^{\mathrm{I} 46}$ Technological change played a role, but only to a certain extent. Workers lost their jobs, but much less to machines than to cheap labour which was readily available outside the factory gates. Exit policies in the guise of "voluntary" retirement schemes reduced the size of the permanent workforce in both large and small companies to a critical minimum. The efficiency drive met with the wholehearted approval of the state bureaucracy which had increasingly come to share the point of view strongly pushed by employers' associations that maintenance of existing labour rights was a major hindrance to accelerating economic growth. The logical outcome of flexibilization of industrial work has been a contraction of production in the formal sector and a further expansion of the informal sector economy. I shall come back to this process of informalization in the final part of my essay.

144. Holmström, South Indian Factory Workers, p. 80.

145. Cited in: Ornati, Jobs and Workers in India, p. 15.

I46. Papola, "Restructuring in Indian Industry", p. 46. 
Scaling down employment in formal sector enterprises improved the bargaining strength of the permanent workers who were reaffirmed in their job security. There is, in other words, a direct link between the privileges granted to a tiny section of the workforce and the marginalization of a much larger segment stuck at the bottom of the industrial economy. Shedding labour considered to be "redundant" meant a heavier workload for those who were allowed to stay on. In return for higher wages they had to commit themselves to a raise in production targets as part of the deal. Moreover, wage hikes were not generously conceded but more often than not had to be fought for by confronting employers head-on.

The changing climate of industrial relations has given rise to a new type of trade union leadership of which Datta Samant in Bombay was a magnificent example. The style of negotiations became confrontational and demands were made without moderation and without heeding legalistic procedures such as arbitration and adjudication. The leader insisted on a united front and demanded total obedience but also promised not to compromise and call off the agitation, usually a strike, until the day of victory. The direct action had only one aim: monetary gains. In this breadand-butter unionism no other issues are at stake than wage rises and a higher bonus or other cash benefits for the permanent workforce in the factory concerned. The relationship between leader and worker is in the nature of a contract that stipulates what both parties can expect from each other and which does not bind them mutually beyond the outcome of the strike. In this scenario the union boss is the leader of a campaign more than the head of a standing organization. He neither wants to be bothered about problems, grievances and requests from individual workers, nor is he deeply interested in ideological issues or the working-class movement at large. In case of failure he simply moves on to the next target which might turn out to be an enterprise in a different branch of industry. Before the start of each direct action the financial standing and ability to pay of the company concerned is scrutinized in order to calculate what can be squeezed out of capital. It is quite clear that when outlay on labour is not of critical importance in the total cost of production, management is much more eager to settle the dispute than in industries where wages are pegged at one-fourth or one-third of manufacturing costs. The failure of the huge textile strike in $1982 / 83$ in Mumbai, which lasted for eighteen months and in which more than 200,000 workers took part under the leadership of Datta Samant, should be seen in this light. The defeat certainly affected his reputation, but only for a short time and not in branches of industry which were more capital-intensive.

The aggressive leadership stands in marked contrast with the lack of militancy of conventional unions which stick to the legalities in their bargaining procedures. Mavericks like Datta Samant ride roughshod over the industrial landscape and lure workers away from the established leaders who 
know best how to take care of both the short- and long-term interests of their constituency. The new brand of labour brokers, so the argument continues, not only antagonizes employers but also manipulates the workers into deals which are bound to turn sour. As has been pointed out by several authors, this is a biased opinion which fails to take into account the feelings of disillusion and even resentment among an upper bracket of the industrial labour force against their earlier representatives, the officials of mainstream associations. The combination of working-class radicalism and businesslike unionism is indicative of a new stage of industrial relations. In this regime any appeal to wider solidarities is overridden by narrower interests which find expression in a mood of here and now. To explain such behaviour as a-political would be to misread the assertiveness and self-consciousness of these militant workers. Their social identity differs markedly from the older generation of factory hands.

The traditional stereotype of the industrial worker as an illiterate low-caste migrant, pushed out of the village by unemployment, was dubious at the best of times. Now it is becoming more untrue with each passing day. Most enterprises in the organized sector would not consider for employment anyone without a schoolleaving certificate, and the presence of graduates and post-graduates in the bluecolour workforce has long ceased to be a novelty. For the skilled trades, a technical diploma from an industrial training institute is an additional advantage. With wages so attractive and employment so scarce, the blue-collar workforce too become(s) a polyglot mix of workers from various castes and religious backgrounds. ${ }^{\mathrm{I} 7}$

How did the targeted managements react to the radical union politics with which they were confronted? That very much depended on their readiness to adjust to the new times and to make a distinction between style and substance. There were those who took offence and showed immense annoyance at being addressed in a manner which did not acknowledge their authority and superiority. Others responded in businesslike fashion and clinched deals which still gave them the upper hand. In exchange for an increase in the wage packet they insisted on getting more out of their better-paid workforce in terms of higher productivity, by including in the agreement clauses on heavier workloads, incentive schemes and lower rates of absenteeism. It was not rare at all for the union which had called the strike to be held responsible for fulfilment by the workers of the stipulations laid down in the new contract which terminated the conflict. By allowing the likes of Datta Samant to operate on their premises, employers hoped to buy industrial peace and a better performing workforce in the bargain. The other side of the story is, of course, that ever increasing benefits were placed in the hands of ever shrinking numbers. As Ramaswamy has aptly remarked, con-

I47. Ramaswamy, "Indian Trade Unionism", p. I70; see also Heuzé, "Workers' Struggles and Indigenous Fordism”, p. 177 . 
tract work, casual labour, redundancy and voluntary retirement create the surplus that is passed on to those left behind in permanent employment. The flow is from one segment of workers to another rather than from capital to labour. ${ }^{148} \mathrm{He}$ follows up this point of view by arguing that ultimately trade unions would have to organize the unorganized out of self-interest if not out of ideology.

Employers who initially did not know how to cope with the phenomenon of independent unions have grown to like them. They do not seem to mind that more workers than ever before have registered as members. What they want for their enterprise is not representation by several unions fighting with each other over the spoils but a strong leader able to instil discipline among his clientele. FICCI, the main association in which the industrialists have organized themselves, has consistently argued in favour of the "one factory, one union" principle. ${ }^{\mathrm{I} 9}$ That preference is strongly inspired by the insight that plant-level unions do not have a wider agenda and are wary of joining national federations which are hand in glove with party politics. The trend reported above, a restructuring of industrial relations in the formal sector of the economy with an emphasis on decentralized bargaining by factory-based unions not federated in national organizations, is in line with World Bank recommendations on how to improve labour standards in countries such as India. In its 1995 Annual Report negotiations at the plant level are praised as the most appropriate framework in which to achieve positive economic effects. But positive effects for whom? One wonders whether the Bank's recipe for "responsible trade unionism" takes cognizance of the vast army of casual and contract labourers moving around as wage hunters and gatherers in the lower echelons of the industrial economy.

\section{INDUSTRIAL WORK IN THE INFORMAL SECTOR ECONOMY}

In the landscape of labour, industrial workers in the organized sector of the economy form a privileged and protected enclave. In the literature they have been identified as skilled factory workers who are permanently engaged ideally in modern enterprises equipped with advanced technology. In addition to their secure employment status they constitute an aristocracy with a befitting social profile and a reasonably comfortable lifestyle. Not least, those who belong to the upper bracket of the industrial workforce have a dignity that derives from their status as organized and legally-protected employees. The moment one tries to specify all these characteristics, however, it becomes clear that they form an ideal type as understood by Weber:

148. Ramaswamy, Worker Consciousness and Trade Union Response, p. 74.

I49. Heuzé, "Workers' Struggles and Indigenous Fordism”, p. I85. 
a compilation of traits which, separately and together, are overexposed and provide a stereotyped image in which the work and lives of only a small minority of plant labourers can be recognized. To put it in yet another way, it is almost impossible to define the average factory hand. The differences among them, between and even within industries, are too great. ${ }^{\mathrm{ISO}}$ Just as stark variations separate the top from the bottom ranks in the superior league, there is no question of a clear and rigid rupture with the world of waged labour outside it. ${ }^{\mathrm{III}}$ The economy thus does not allow itself to be split into two sectors, a formal and an informal, and that also applies to conditions of employment. Holmström has abandoned his earlier stance and has replaced the image of a sharp dichotomy by drawing up a more differentiated chart of the labour terrain, one that is very uneven.

My image of the citadel was too simple. The organized/unorganized boundary is not a wall but a steep slope. Indian society is like a mountain, with the very rich at the top, lush Alpine pastures where skilled workers in the biggest modern industries graze, a gradual slope down through smaller firms where pay and conditions are worse and the legal security of employment means less, a steep slope around the area where the Factories Act ceases to apply (where my wall stood), a plateau where custom and the market give poorly paid unorganized sector workers some minimal security, then a long slope down through casual migrant labour and petty services to destitution. There are well-defined paths up and down these slopes, which are easiest for certain kinds of people. ${ }^{\mathrm{I} 2}$

In abandoning the idea that the economy follows a dualist pattern, Holmström agrees that the world of labour also cannot be divided into two sections of organized and unorganized sector workers respectively. There is no clear dividing line between them. I endorse that observation, but find the lesson that he draws from it, however hesitantly, to be more problematic, namely: that there is only one working class with common interests and a common fate. Following up on the statement made by Ram, that "any one descriptive generalization of the characteristics of the Indian working class simply no longer seems to suffice", ${ }^{153}$ one feels inclined to emphasize the multiple identity of this very diverse and heterogeneous social amalgam of classes. That conclusion forms the point of departure for shifting the focus to industrial employment not within but outside the organized sector of the economy. My analysis deals with both the work process and the social identity of the mass of workers who depend upon it for their existence.

I50. Ramaswamy, "Wealth and Power Convert Into Status", pp. 35-38.

I5I. Harriss, "The Working Poor and the Labour Aristocracy"; Mathur, "The Effects of Legal and Contractual Regulations", p. 189 .

I52. Holmström, Industry and Inequality, p. 319.

I53. Ram, "Indian Working Class and the Peasantry", p. I84. 